\title{
An Old Amharic poem from northern Ethiopia: one more text on condemning glory
}

\author{
Maria Bulakh \\ Russian State University for the Humanities / National Research University Higher School of \\ Economics, Moscow \\ mbulakh@mail.ru
}

Denis Nosnitsin

University of Hamburg

nosnitsin@yahoo.com

\begin{abstract}
This article presents a publication and translation (with linguistic and philological commentaries) of a recently discovered piece of Old Amharic poetry, possibly dating to the first half/middle of the seventeenth century. The published text bears the title Märgämä kabr ("Condemnation of glory"), but its content differs from that of several other Old Amharic poems (not entirely independent from each other) known under the same title. It is only the general idea and the main topics that are shared by all Märgämä kabr poems: transience of the earthly world, the inevitability of death and of God's judgement, and the necessity of leading a virtuous life. One can thus speak of Märgämä kabr as a special genre of early Amharic literature, probably originally belonging to the domain of oral literature and used to address the Christian community with the aim of religious education and admonition of laymen.
\end{abstract}

Keywords: Old Amharic, Ethiopian literature, Amharic literature, History of Amharic language, Early Amharic poetry, Ethio-Semitic linguistics

The overall number of known texts bearing witness to the early stages of the Amharic language ${ }^{1}$ and early Amharic literature has been gradually increasing in recent years, but we are still in the process of acquiring data, so that each new text in an older variety of Amharic is important and valuable and can lead to a revision of current views. The recent research work of the project Ethio-SPaRe in northern Ethiopia (Tigray) ${ }^{2}$ resulted in the finding of many

1 The features of Old Amharic have been discussed in various publications of Old Amharic texts and scholarly studies, in particular the recent book by Girma Awgichew Demeke (2014). Following this author (ibid., p. 3), we will use the term "Old Amharic" to refer to the form of Amharic spoken and written in Ethiopia before the eighteenth century (with the earliest texts possibly dating from the fourteenth century). Some evidence on the earliest known stages of Amharic is contained in the so-called Arabic-Ethiopic Glossary (Bulakh and Kogan 2016).

2 The project Ethio-SPaRe: Cultural Heritage of Christian Ethiopia - Salvation, Preservation, and Research, funded by the European Research Council under the $7^{\text {th }}$ 
previously unknown manuscripts with Amharic texts, a few of which are definitely older than the nineteenth century. A poetic text of this kind, contained in a parchment manuscript uncovered by the project, will be discussed below. ${ }^{3}$ A brief description of the manuscript will be provided, followed by the text and its translation, a thorough discussion of its language, a survey of related witnesses, and a note on its genre and literary properties. ${ }^{4}$

The church where the text was found is known as Läq̆ay Kidanä Məḥrät (wäräda Ganta 'Afäšum, East Tigray), located close to the city of 'Addigrat." The text to which the present study is devoted is contained in one of the most interesting items in the church library, ${ }^{6}$ the codex which has received the project signature MKL-008. ${ }^{7}$

\section{MKL-008 Mäṣhafä qaddase, Missal}

MS MKL-008 is a Missal, i.e. the manuscript containing Mäṣhafä qaddase ${ }^{8}$ ("Book of the Hallowing"), which is a more or less fixed compilation of

Research Framework Programme IDEAS (Independent Researcher Starting Grant 240720) ran from December 2009 to May 2015 (https://www.aai.uni-hamburg.de/en/ ethiostudies/research/ethiospare.html), with its seat at the Hiob Ludolf Centre for Ethiopian Studies, Hamburg University (https://www.aai.uni-hamburg.de/en/ ethiostudies.html).

3 Poetic compositions written in manuscripts constitute a distinct group of sources in Old Amharic. Getatchew Haile (1979a, 1991, 2005, 2014) and Gideon Goldenberg (2013) are the only scholars to have published any of these texts in recent years.

4 While this article is the product of joint work, there was a separation of competence, in the best tradition of multidisciplinary research. Part III was penned predominantly by Maria Bulakh, while parts I, IV, and V were compiled mostly by Denis Nosnitsin. The edition and the tentative translation of the text, presented in part II, are the result of our united efforts. Denis Nosnitsin has carried out part of his research within the framework of the long-term project "Beta mașāhəft: Manuscripts of Ethiopia and Eritrea", funded by the Academy of Sciences and Humanities in Hamburg (https:// www.betamasaheft.uni-hamburg.de/). Maria Bulakh's work was supported by the Russian Science Foundation, grant \#16-18-10343. Warm thanks are due to Orin Gensler for amending the English style and for a number of penetrating remarks and comments. We are deeply grateful to the anonymous reviewers whose critical observations and suggestions have helped to improve the text considerably. Needless to say, all remaining errors are ours.

5 A preliminary survey has been provided recently (Nosnitsin 2013: 155-8); the area has been briefly investigated by archaeologists and found to be of potential interest (Sernicola 2012).

6 The entire manuscript collection of the church comprises $c$. 30 manuscripts. The oldest, dating from $c$. mid-fifteenth-early sixteenth century, is MKL-002, Tä'ammərä Maryam ("Miracles of Mary"). The Four Gospels book of the church, MKL-005, dates to the time of King Täklä Giyorgis (reigned during several periods between 1779 and 1800). Some other books of the collection are interesting and valuable, though none predates the sixteenth century; one of them, MKL-016 Gädlä Kiros ("Acts of Kiros"), has recently been treated in a more detailed way, see Krzyżanowska 2015.

7 A preliminary description of the manuscript has been compiled for the Ethio-SPaRe database by Iosif Fridman.

8 Transliteration of Geez, Amharic and Tigrinya throughout this article mostly follows the principles of Encyclopaedia Aethiopica. Quotations from Leslau (1987) have been 
liturgical texts used in the Mass. Some of the constituent parts of the Ethiopic Missal (e.g. some of the Anaphoras) have been extensively studied, ${ }^{9}$ but the text organization and material structure of the text carriers, as well as individual Missal-manuscripts, have rarely been discussed in scholarly works dedicated to Geez literature. However, the Missals are omnipresent in the ecclesiastical libraries and comprise a significant part of the Ethiopian manuscript heritage.

MS MKL-008 belongs to the group of pre-eighteenth-century Missals recorded by the project team. ${ }^{10}$ Originally a good quality book, MKL-008 was used intensively and is thus in poor condition. The text in question (referred to here as MärKL) is an added text contained on two folia, ff. 141-2. MKL-008, previously unknown and undescribed, is a very complex manuscript. Its description below is intended to help in estimating more correctly the age and the function of both the main text and MärKL, and their relation to each other.

\section{Physical description}

Outer dimensions $(\mathrm{cm})$ : $18.0(\mathrm{~h}) \times 15.5(\mathrm{w}) \times 6.0(\mathrm{t})$.

Binding: The codex has the typical Ethiopian binding. It was originally composed of two wooden boards covered with reddish-brown tooled leather. The front board is now missing; it has been replaced with an improvised construction made of recent newspaper and schoolbook. The back board is split and repaired with wire; it is decorated with a recent, crudely carved cross. Only the tooled turn-ins remain from the leather covering, on the inner side of the back board. The volume is sewn on two pairs of sewing stations.

MS MKL-008 is composed of $151 \mathrm{ff}$. in 17 quires.

Quire structure: $I^{(10 / f f . ~ 1 r-10 v)}-I^{(10 / f f . ~ 11 r-20 v) ~}-I^{(10 / f f . ~ 21 r-30 v) ~}-~ I V^{(10 / f f . ~ 31 r-40 v) ~}$

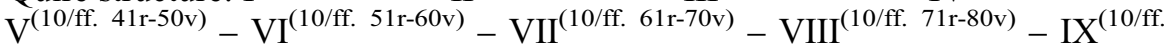

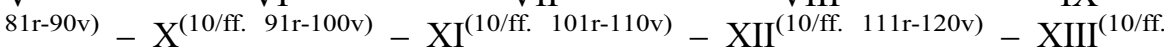

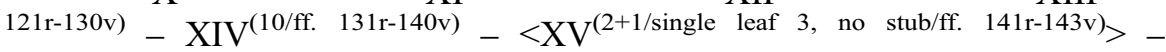
$\mathrm{XVI}^{(2 / \mathrm{ff} .144 \mathrm{r}-145 \mathrm{v})}-\mathrm{XVII}^{(6 / \mathrm{ff} .}$ 146r-151v).

Almost all the surviving regular text quires of MKL-008 are "quinions" composed of bifolia; no single leaves were used except for quire XV (see below). In the current condition of the manuscript, at least one quire at the beginning is missing (see below, "Content"). The original place of quire XV, which contains the text under scrutiny, is unclear. In the present condition, it is composed of only one bifolio (ff. 141-2, leaves i and ii) and one singleton (f. 143), crudely attached with wire. Both the bifolio and the singleton could have been inserted at the end of the volume later, and put at their present place by chance, as the result of damage and improper handling of the manuscript. Probably for the same

modified accordingly. The names of languages (Geez, Tigrinya) are given in conventional English orthography (rather than in transcription).

9 See, e.g., Hammerschmidt 1987, and more recent overviews in Fritsch 2001 and Bausi 2010.

10 The Ethio-SPaRe project team has recorded a few hundred Missals, of which 93 are described in the project's database. Of these, there are some 11 Missals which are considered to be of pre-eighteenth-century date; the oldest of them, AKM-009 ('Ambäsät Kidanä Məhrät), has been provisionally dated to the first half of the seventeenth century. 
reasons, the structure of the quires XVI-XVII is disturbed and their leaves are misplaced (cf. below).

Layout: two columns (quires I-XIV, XVI-XVII) [one column for ff. 141-2, quire XV].

Written area $(\mathrm{cm}): 9.5(\mathrm{~h}) \times 11.5(\mathrm{w})$.

Palaeography: The script dates to the first half of the seventeenth century or slightly later; ${ }^{11}$ the writing was executed by a well-trained, very careful scribe (see Figure 1).

The script is tall, rounded, very slightly slanted to the right.

The tops of the letters $\boldsymbol{\sigma v}, \boldsymbol{\omega}, \boldsymbol{m}, \boldsymbol{w}$ are slightly and uniformly slanted to the left. The vertical strokes strive to be parallel, but the legs of $\Omega$ or $\boldsymbol{\lambda}$ are slightly convergent (the bend of the left leg is slightly more pronounced).

The "feet" of the letters are rectangular, sometimes with very short hairlines. The serifs are forked.

The numerals are styled with thin red and black dashes above and below (ff. 31rb, 32ra, 34ra-b, 45vb, 47va, 52va, or 84va, 144ra-b, etc.).

Rubrication is carried out very carefully, in the main hand. ${ }^{12}$

\section{Content}

The manuscript contains a collection of texts used in the Mass of the Ethiopic Orthodox Church (Mäṣhafä qaddase):

I) Prefatory service (Śrr atä qaddase "Order of the Mass") (ff. 1ra-30va), incomplete, the beginning is missing ${ }^{13}$

II) Anaphoras (ff. 30vb-146rb)

II-1) Anaphora of the Apostles (ff. 30vb-44vb)

II-2) Anaphora of Our Lord Jesus Christ (ff. 44vb-49vb)

II-3) Anaphora of St. John Chrysostom (ff. 50ra-63va)

II-4) Anaphora of Our Lady by St. Cyriacus of Behnesa (ff. 64ra-77rb)

II-5) Anaphora of St. John Chrysostom (ff. 77va-84va)

II-6) Anaphora of the 318 Orthodox Fathers of Nicaea (ff. 84va-95vb)

11 Uhlig (1988: 425) indicates a number of manuscripts showing a stage of script development which precedes the full formation of the Gondärine script (the so-called $g^{w}$ alh). MS MKL-008 can be considered as belonging to this group. The traits of the handwriting mostly fit the characteristics described for the period mid-sixteenth-mid-seventeenth century (Uhlig 1988: 425-544). In particular, the handwriting of MKL-008 shows some similarity to such samples used in Uhlig 1988 as MSS London BL Or. 732 (Uhlig 1988: 467-77), Or. 644 (480-1), Or. 754 (486-7) or Or. 518 (498-9).

12 A brief reflectographic examination of the inks of MKL-008 with microscope dinolite Pro2 AD413T-I2V, carried out in May 2014, showed that the black ink of the main text is - as expected - of the most common carbon type. The red ink appears to be of plant type, possibly with very slight admixture of mineral components (cf. Rabin 2014: 302-5).

13 The beginning (f. 1ra: ...lä-'ogzi' ənä wä-mädhaninä wä-'amlakənä 'Iyäsus Krastos. Zä-'aqüma lä-betä krastiyan...) corresponds to ch. $1, \S 1$ in the "Order of the Mass" of the contemporary Missal (Mäșhafä qaddase 1962 A.M., Śr r'atä qaddase ch. 1, §1). However, a substantial portion of the text is missing, more than a few lines as compared with the modern Mäșhafä qaddase. The missing portion might be a single leaf or a whole quire. 


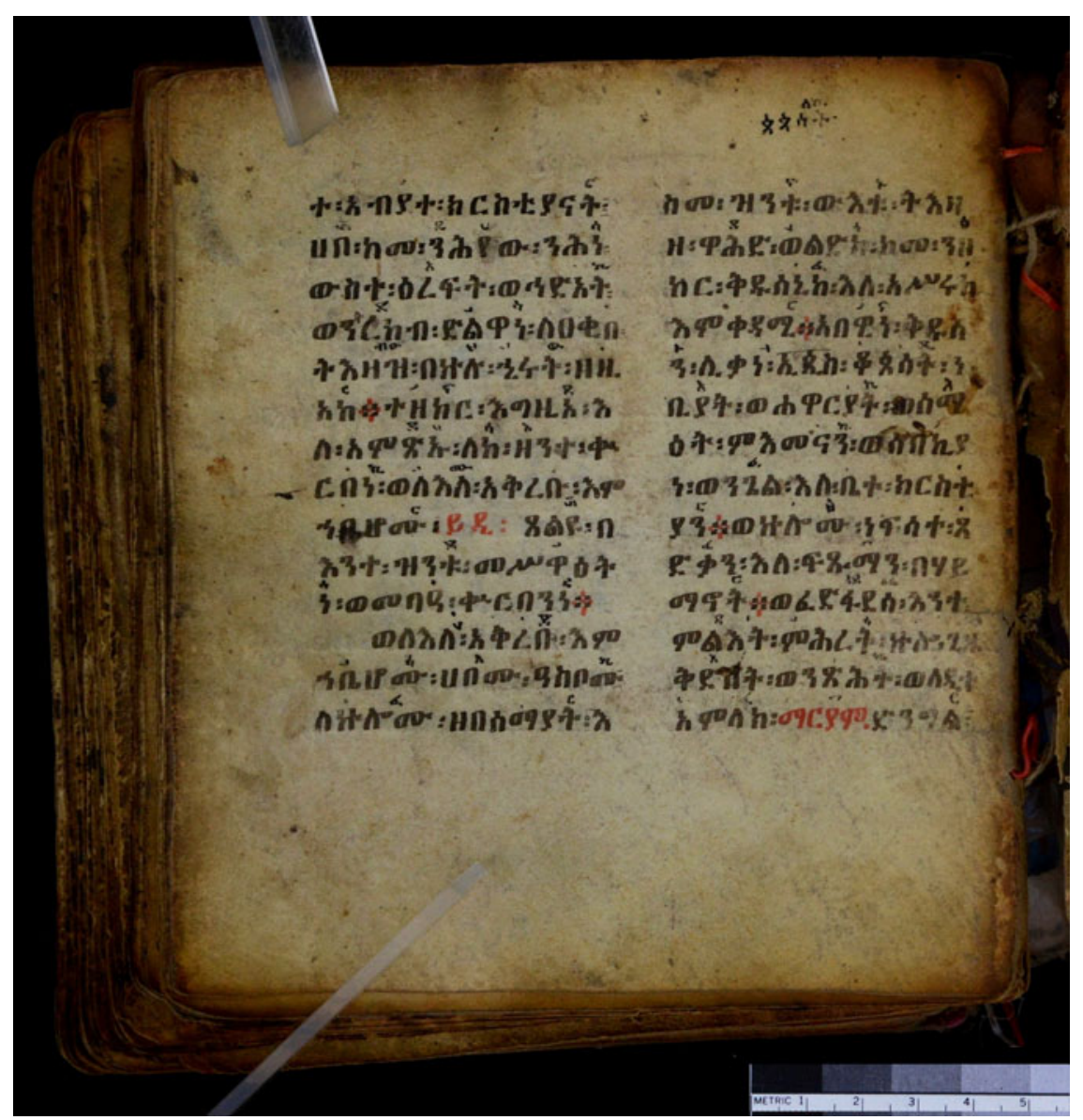

Figure 1. (Colour online) MS MKL-008, Läq̌ay Kidanä Məḥrät (Ethiopia), 1650-60, f. 140v [Mäṣ̆hafä qaddase]

II-7) Anaphora of St. Gregory of Nyssa (ff. 95vb-109rb)

II-8) Anaphora of St. Dioscorus of Alexandria (ff. 109rb-112vb)

II-9) Anaphora of St. Jacob of Serug (ff. 112vb-121ra)

II-10) Anaphora of St. Athanasius of Alexandria (ff. 121rb-135rb)

II-11) Anaphora of St. Basil of Caesarea (ff. 135rb-140vb, 144ra-vb, 148ra-vb, $147 \mathrm{ra}-\mathrm{vb}, 146 \mathrm{ra}-\mathrm{b})$

The set of the Anaphoras in MS MKL-008 is somewhat different from the common 14 Anaphoras in the contemporary official church editions of Mäṣafä qaddase: ${ }^{14}$ the Anaphoras of Epiphanius, Cyril and Gregory Thaumaturgus are missing. ${ }^{15}$

Apart from the main texts, the manuscript contains a number of smaller texts added later in the blank spaces (additiones), mostly of liturgical content: 


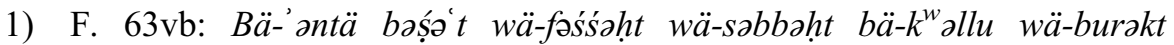
wä-nəșaht 'agzi'tənä wäladitä 'amlak Maryam... Excerpt from the Anaphora of Our Lady by St. Cyriacus of Behnesa ${ }^{16}$

2) ff. 141r-142r: Märgämä kabr "Condemnation of Glory", a didactic poem [MärKL]

3) f. 143ra-vb: Three short prayers written in the same secondary hand, unidentified

3a) Sälot la lä hobostä 'awlogya, "Prayer over the blessed bread"

3b) Sälotä ma' add ' əm-dəhrä bäli", "Prayer at the table after meal"

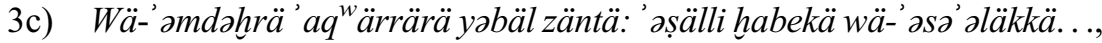
Prayer after the cooling down (of the Eucharistic bread?)

The rest of the additiones are presented below according to the reconstructed sequence of the leaves (iv-viii) as they would have been accommodated in a quire, probably "quaternion", which originally might have been the ultimate one (if we assume that the quire containing MärKL was the last quire). ${ }^{17}$

4) ff. 146va-b (=leaf iv-verso), 151ra-b (=leaf v-recto): Bä-zä nəzzekkär hasabä həggu lä-' agzi' ənä 'iyäsus krastos 'ənzä hallonä bä-zämänä Matewos..., Prayer while burning the incense, for the sake of commemorating various saints, which contains the date of writing: 7277 Year of Mercy, 20th day according to the lunar calendar, 15th day of the solar calendar of the month of Ganbot (f. 146va). However, the second and third numerals in the year number were corrected. The year 7277 is equivalent to $1785 \mathrm{AD}$. In the bottom margin, there is the word 'argätu ("His (/the) ascension") in a thin black frame

5) ff. 151va-b (=leaf v-verso), 150ra-b (=leaf vi-recto), 150va, lines 1-9 (=leaf vi-verso): Sälam lä-k $k^{w}$ allakəmu 'agzi'abəher 'agzi' anä 'Iyäsus Krastos 'amlakənä zä-tabelo lä-faqurəkä Yohannəs... Excerpt from a liturgical text

6) f. 150va, lines 10-15 -vb (=leaf vi-verso): 'Gllä mäsa'kəmu 'allä tägaba'kəmu wä-'allä șälläykamu wastä zatti qaddast 'ammənä betä krostiyan..., Prayer for those gathered in the church(?)

7) ff. 149ra, lines 1-7 (=leaf vii-recto): Täsahalkä 'agzi'o madräkä..., Short excerpt from a prayer or hymn ${ }^{18}$

8) ff. 149ra, lines 8-14 -rb (=leaf vii-recto), 149v (=leaf vii-verso), 145r (=leaf viii-recto): Mästäbq $q^{w}$ ' bä-' zntä mutan, "Supplication for the dead", ${ }^{19}$ partly with musical notation signs; other supplications

16 See Mäșhafä qaddase 1962 Am: 18 (§§11-2).

17 In Denis Nosnitsin's opinion, the first half of the quire had the following sequence of leaves: f. $144=$ leaf i; f. 148 = leaf ii; f. 147 = leaf iii; f. 146 = leaf iv (the recto-side contains the explicit of Text II-11, see above).

18 In which St. Mary is called sämay dagamit, "the second Heaven" (cf. Grohmann 1919: 308).

19 See Mäṣhafä qaddase 1962 AM: 290-1. 
9) f. $145 \mathrm{v}$ (=leaf viii-verso): ${ }^{20}$ Prayer before the liturgical reading from the Gospel $^{21}$

\section{Varia and paratexts}

Omitted portions of text have been carefully reintegrated in the margins in a different hand, and their places in the main text have sometimes been marked with so-called tie-marks (Amh. tämälläs).

For some of the Anaphoras, indications concerning the celebration dates (names of the feasts) have been added in the upper margin. Musical notation signs have been added above the lines for a large part of the main text, most probably somewhat later, in a different hand.

Commissioners and donors: The name of the commissioner appears in the supplication formula on f. $33 \mathrm{vb}$, but it is half-erased, only the second part being readable: $<\ldots>$ [Mä]dhən. There is no further indication concerning the identity of this person.

Dating: The dating for MKL-008 can be established on the basis of internal evidence. Several historical personalities are referred to in the book. Marqos, mentioned as the patriarch of Alexandria (see ff. 113ra, 144vb, etc.), is Mark VI, in tenure from 1645 to 1660; and Mika el, the metropolitan of Ethiopia, was in office from 1650 to 1663 (see ff. 13rb, 15vb, 113ra). King Fasilädäs, mentioned on $\mathrm{f}$. 13rb, reigned 1632-67. The resulting copying date of the manuscript is $1650-60$.

Concerning the dating of ff. 141-2: The bifolio containing MärKL is worn, dirty and bears traces of wax, and is in some parts hardly readable. It is accommodated in a single column, the layout pattern being different from that of the main text. The irregular form of the leaves, and some disparate (erased) writing upside-down on f. 142v, may indicate that remainders of parchment (not good enough for regular text leaves) were utilized for the bifolio. The physical consistency of the parchment used for the bifolio appears somewhat different from the parchment of the textblock leaves. ${ }^{22}$

The palaeographical evidence from the manuscript turns out to be essential. If one looks closely at the hand of MärKL and the hand of the main text, one notices some differences in the general appearance ${ }^{23}$ and in the quality of the script execution. ${ }^{24}$ However, these can be at least partly explained though the "auxiliary" character of MärKL, which was of lower status in comparison with the main text and hence permitted scribal work of an inferior quality. It is difficult to find substantial and persistent differences in individual

20 The reconstruction seems to be confirmed by the condition of leaf viii-verso (f. $145 \mathrm{v}$ ), very worn and dirty, indicating that it might have been the outer leaf of the quire.

21 See Mäshafä qaddase 1962: 42-3, §§186-7.

22 Cf. the traces of blood vessels in the parchment clearly discernible in the (lower) margins, absent in the regular text leaves.

23 The script of MärKL looks less elegant; the height of the letters is slightly less and some letter shapes are broader (esp. $\boldsymbol{\sigma o}$ ); the tops of the letters are parallel to the lower ruled line; the vertical lines are upright; there is a tendency to rectangularity. "Hairlines" are strongly articulated.

24 The lines of the hand in MärKL are frequently hesitant, some letters are slightly misshapen, some vertical lines are bent, there is no rubrication, the serifs are executed less clearly and are rather "flagged", not forked, etc. 
letter-shapes which would clearly demonstrate that the texts were written by two different scribes. ${ }^{25}$ To the contrary, it appears quite possible that both texts were executed by the same scribe. If this assumption is correct, the relationship between MS MKL-008 and MärKL can be represented as follows. The scribe copied the main text of MS MKL-008 around 1650-60; the same scribe could have copied MärKL on a separate bifolio which was later added to the textblock of MKL-008. The composition of the original text of MärKL could have taken place in the first half or around the middle of the seventeenth century (see III.8).

\section{The poem in Old Amharic}

The text under study is a poem in Old Amharic entitled Märgämä kabr, "Condemnation of glory" (hence MärKL), an appellation that has become known thanks to two recent publications of Getatchew Haile. ${ }^{26}$ Below, the text is reproduced exactly as it appears in the manuscript (cf. photos in Figures 2, 3, and 4), and supplied with a tentative translation (some passages still remain obscure or ambiguous).

In the Amharic text column, subscripted small numbers in square brackets refer to the physical written lines; the arrangement of the Amharic text and the numbers in the translation column refer to the editors' division of the text into verses. The square brackets in the Amharic text indicate the editors' reconstruction of barely discernible letters (a dot under the letter means complete illegibility and physical destruction of the sign). Triangular brackets mark the editors' reconstruction of letters/words omitted by the scribe. Dashes above and below an erroneously written letter indicate the scribe's immediate correction. Curly brackets mark letters inserted interlinearly.

25 One rather finds hints to the contrary, sometimes in those letters where the distinctive traits of the scribal hand would be expected to be conspicuous: cf. (in both texts) the strongly accentuated vertical downstroke in $\mathrm{F}$, with the body of the letter raised high (cf. f. 140vb, 11. 9 and 10 against f. 141r, 11. 10 and 11); the same for 4 (f. 140va, 1. 5 against f. 141v, 1. 6); $A$ with the left downstroke tending to be straight, right downstroke slightly bent, and small closed "inner loop" (the marker of the sixth order) (ff. 140vb, 1.8 and $141 \mathrm{r}, 1.5$ ); in particular $\ell_{0}$, with the fifth-order marker (a small ring) being a rightward extension of the horizontal line below (not set up under it, and not on an additional short vertical/oblique line); the sixth-order marker ("kink") in h shaped not very conspicuously (in MärKL, due to a less careful execution, the marker looks like a small "tooth", sometimes barely discernible, cf. III.2.1); the numerals 1 (므) and 3 (ㄹ) $)$ are written in a similar way, and with dashes above and below (but in MärKL there are no rubricated elements at all).

26 Getatchew Haile 2005; 2014. In the translation of the title, we have followed the wording of Getatchew Haile 2005: 265. 


\begin{tabular}{|c|c|}
\hline (f. 141r) ${ }^{\sigma D} C \mathrm{C}^{\sigma D}$ : hnC & Condemnation of glory \\
\hline 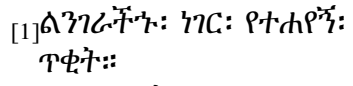 & $\begin{array}{l}\text { 1) Let me tell you a little about a matter }{ }^{27} \text { that } \\
\text { appeared to me. }\end{array}$ \\
\hline 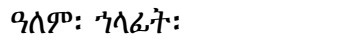 & 2) The perishable world \\
\hline 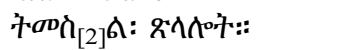 & 3 ) is like a shadow. ${ }^{28}$ \\
\hline 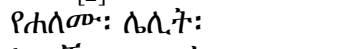 & 4) What they dreamt at night \\
\hline 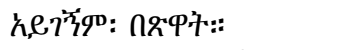 & 5) will not be found in the morning. \\
\hline 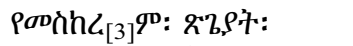 & 6) The flowers of Mäskäräm \\
\hline 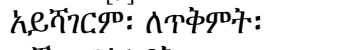 & 7) will not last into Taqamt. \\
\hline 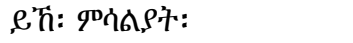 & 8) These are the parables \\
\hline$\Lambda 9 \Lambda 90: n_{[4]} h+2:$ & 9) of a wicked world, \\
\hline 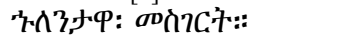 & 10) whose entirety is a snare. \\
\hline 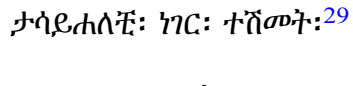 & $\begin{array}{l}\text { 11) (The world) will show you a matter }{ }^{30} \text { with } \\
\text { appointments - }\end{array}$ \\
\hline 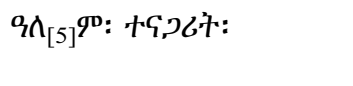 & 12) (namely,) the world which speaks (in vain) ${ }^{31}$ \\
\hline 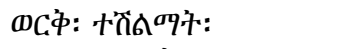 & 13) gold with an award, \\
\hline b.Lì: thrnta: & 14) a stallion with weapons, ${ }^{32}$ \\
\hline 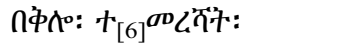 & 15) a mule under horsecloth, \\
\hline 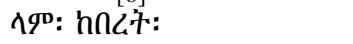 & 16) a cow inside a stall, \\
\hline 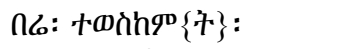 & 17) an ox with a nose-ring, \\
\hline hก.: hรา': & 18) a pregnant cow with a nursing cow, ${ }^{33}$ \\
\hline 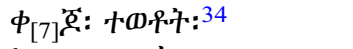 & 19) a straw vessel ${ }^{35}$ with milk, \\
\hline 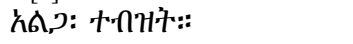 & 20) a bed under a bed-cloth, ${ }^{36}$ \\
\hline 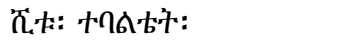 & 21) perfume on a lady, \\
\hline 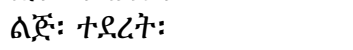 & 22) a child at the breast, \\
\hline${ }_{[8]}^{\sigma D h C: ~+T h: ~}$ & 23) a harvest of grain, \\
\hline 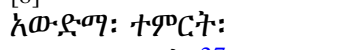 & 24) a threshing-floor with crops, \\
\hline 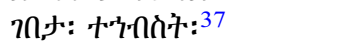 & 25) a table with bread - \\
\hline
\end{tabular}

Continued

27 Here the word nägär is used in the most common sense ("matter, thing, affair", cf. Kane 1990: 1061).

28 cp. Ps. 143:4; Job 8:9, 14:2.

29 On the form ${ }^{2} \sigma o$ 市 cf. III.6.1.

30 It is not clear which sense of the word nägär is intended here: either more general "matter, thing, affair" (as above, cf. n. 27), or the specific "court case, dispute" (cf. Kane 1990: 1061).

31 The translation of lines 4-5 (verses 11-12) is very uncertain; the text is possibly corrupt. In the current version, we consider the word $9 \Lambda 9 \mathbf{9}$ (with an attribute $+9, \mathbf{C}^{2}$ ) as the subject of the verbal form , ti,edite.

32 Kane 1990: 2149: țäbt "defensive and offensive weapons" (see Guidi 1889: 65, song XI, line 2; Littmann 1943: 498; cf. also Mersha Alehegne 2011: 678).

33 Kane 1990: 2183: țggä̈t "milk cow (which has milk, is not dry)" (cf. III.3.2).

34 On the form $\omega$. 许 cf. III.6.2.

35 Kane 1990: 824: qeğo or qüğo "straw vessel used for milking or for fetching water".

36 Kane 1990: 931: bazzat "cotton or wool which has been fluffed"; cf. also Gez. bazzat "linen, wool" (Leslau 1987: 118).

37 On the form "trnit instead of the expected "rndit cf. III.2.2. 


\begin{tabular}{|c|c|}
\hline (f. 141r) ${ }^{a D} C 7^{\sigma D}: h+\cap C$ & Condemnation of glory \\
\hline 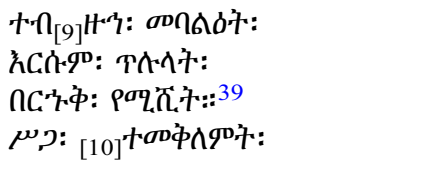 & $\begin{array}{l}\text { 26) with many dishes, } \\
\text { 27) those not for fasting days, }{ }^{38} \\
\text { 28) fragrant from afar }- \text {, } \\
\text { 29) meat with a knife, }{ }^{40}\end{array}$ \\
\hline 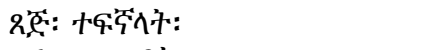 & 30) țäğğ in bowls, ${ }^{41}$ \\
\hline 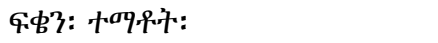 & 31) a ewer on a stand, ${ }^{42}$ \\
\hline 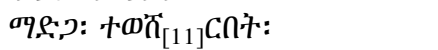 & 32) a jar ${ }^{43}$ with a pot. ${ }^{44}$ \\
\hline 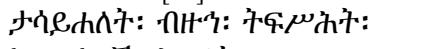 & 33) (The world) will show you much joy, \\
\hline : 幺a-לे: & 34) (but) let it not appear like truth to you, \\
\hline [ל. & $35)$ there is $\sin$ in it. 45 \\
\hline 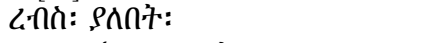 & 36) That which has profit, \\
\hline 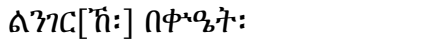 & 37) let me tell you about its benefit: ${ }^{46}$ \\
\hline 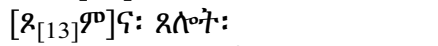 & 38) fasting and prayer, \\
\hline 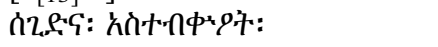 & 39) prostration and supplication, \\
\hline 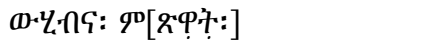 & 40) charity and alms. \\
\hline 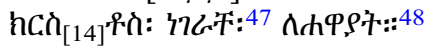 & told the Apostles: \\
\hline †าก: ฮอไๆ & 42) you $^{49}$ will enter the kingdom of heave \\
\hline 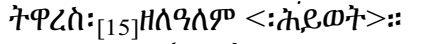 & 43) you will inherit the eternal $<$ life $>.50$ \\
\hline ҺPQ: & 44) Look, ther \\
\hline eava: ก.e:37': & 45) (which) will come unexpectedly. \\
\hline D: $[16] \delta \Lambda+:]$ & 46) (Death) will not tell me the day, \\
\hline 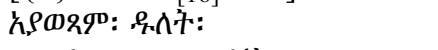 & 47) nor will it convene an assembly, ${ }^{51}$ \\
\hline 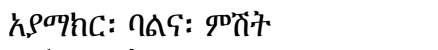 & 48) nor take advice from husband and wife, \\
\hline 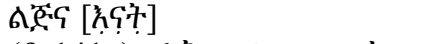 & ild and mother, \\
\hline (f. $141 v$ & 50) neighbourhood and neighbour, \\
\hline
\end{tabular}

38 Kane 1990: 2089: tolulat "milk, butter, eggs or meat or dishes made from them which may not be eaten on fast days".

39 On the form Pardit cf. III.1, III.6.3.

40 Kane 1990: 236: mäqlämt "a small knife used in cutting meat", Gondär usage. Cf. also wäqlämt in Mersha Alehegne 2011: 678.

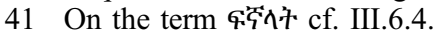

42 Kane 1990: 2300: faqen, faqün "ewer, container for water"; Kane 1990: 250: matot "ring of leather or grass used to support a round-bottomed vessel, stand, support".

43 Kane 1990: 332: madagga "earthenware jar".

44 On the term $\omega^{\top} \mathrm{n} C \mathrm{n}$ t cf. III.6.5.

45 The literal translation of verses $34-5$ is: "Let not what contains sin appear like truth to you".

46 The literal translation of verses $36-7$ is: "Let me tell you about the benefit which has profit in it".

47 On the form inct cf. III.1.

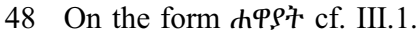

492 sg. masc. The same form is used in verses 43 and 44.

50 The reconstruction of the final word h,e $\omega$ 午 is suggested by the following considerations: the rhyme in final $-t$ is characteristic for this section of the poem; the syntax of the phrase demands an explicit direct object; the noun h,e in verse 91, and a semantic parallel in verse 112); the similarity of h,e word $\boldsymbol{h} \rho \boldsymbol{\omega} \cdot$ - suggests an omission by (quasi)homoeoarcton.

51 Kane 1990: 1711: dulät "assembly (to discuss rotation of office)". 


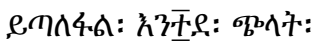

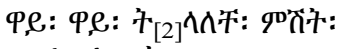

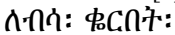

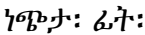 \\ ९Ф2.

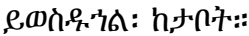 \\ eavhr: hus':

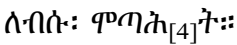 \\ eн:

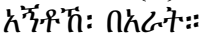 \\ 73н'n: 0ל一:

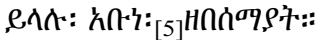

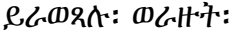 \\ eH: int:

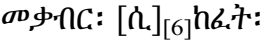 \\ $\rho \Lambda\{\cap\} \hat{k} \cdot \boldsymbol{\prime} \Lambda:$

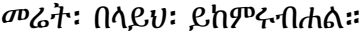

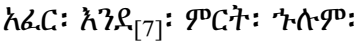 \\ , \\ hกt:

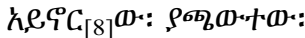

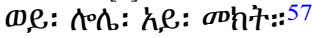

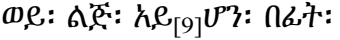

51) (rather) it snatches like a hawk.

52) The (widowed) wife will wail,

53) having put on a hide,

54) having scratched (her) face..$^{52}$

55) They will carry you out on two (pieces of) wood, 53

56) they will bring you to the tabot. ${ }^{54}$

57) The priests will come,

58) having put on (their) sticharion,

59) having taken the censers,

60) having laid you upon a bed,

61 ) having wrapped you in a mat, ${ }^{55}$

62) they will say the Pater Noster.

63) The young men will run,

64) having taken sabät. ${ }^{56}$

65) While the grave is open,

66) they will dress you (with earth),

$67)$ they will heap earth upon you.

68) Everyone returns to soil, like the plants.

69) Woe, (in death) none will have a single servant from home to entertain him,

70) woe, a servant will not protect (him),

71) woe, a son will not be ahead (of him),

Continued

52 Cf. Mahtämä Səllase Wäldä Mäsqäl 1962 AM: 587.

53 A kind of stretcher made of wooden poles is meant here, which was used in Christian Ethiopia for transporting the wrapped corpse to the burial place ("couch" in Parkyns 1853, vol. II, 60-1 [ch. Xxx]; cf. "bier" in Walker 1933: 52-7; see also the picture printed in Pankhurst 1990: 197, showing the transportation with two wooden poles; cf. somewhat different depictions in Chojnacki 1983: 322, figs 143b, p. 323, fig. 144b).

54 The verse alludes to a constituent element of the funeral ritual of the Ethiopian Orthodox Church, the "greeting of the tabot by the deceased" (on the tabot, the consecrated stone or wooden slab sometimes described as "altar tablet" and present in each individual Ethiopian church, see Heldman 2010: 802-4 and Fritsch 2010: 804-7). According to the contemporary version of the Mäșhafä gənzät ("Book of the Funeral Ritual"), after the funerary procession has passed all seven "stations" (məraf), the body is to be brought to the church and then introduced inside (this is the last, eighth "station" of the ritual). If the deceased was a priest or deacon, the dead body should be brought into the sanctuary (mäqdäs, the sacred area where access is absolutely prohibited to the layman, cf. Fritsch 2007: 765-7) and placed near the "altar", i.e. the tabot (or, rather, a special chest where the tabot is usually accommodated). At that moment, a special "prayer of greeting" (șälotä ' ammahe) should be read. But those who are neither priests nor deacons should be placed only outside of the church, at an entrance ('af a betä krastiyan) (see Dobberahn 1997, I, 46, 242-3; II, 873, 1007-8). The poem does not specify who are those brought in to the tabot, possibly meaning equally all the dead without distinction.

55 Kane 1990: 1040: nät "mat of tanned oxhide". Cf. also Gez. nät "scarlet; scarlet garment" (Leslau 1987: 406-7).

56 On the obscure form inn' cf. III.6.7.

57 On the separate writing of he, cf. III.2.5. 


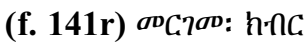

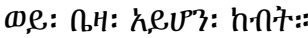

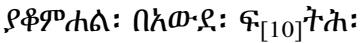

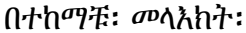

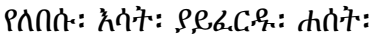

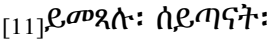

,

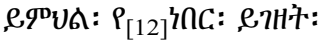

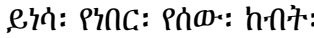

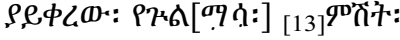

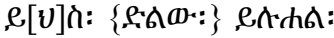

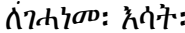

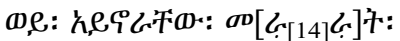

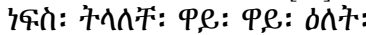

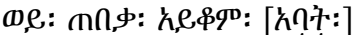

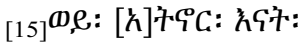

ae: h,

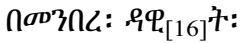

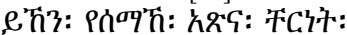

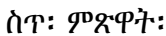

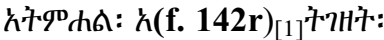

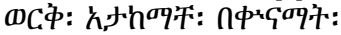

+中

त身早:

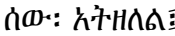

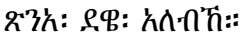

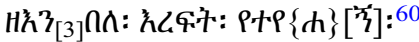

ento:

[4]

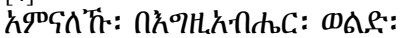

久

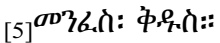

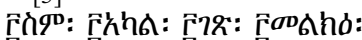

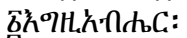

Condemnation of glory

72) woe, the cattle will not serve as a ransom (for him).

73) (God) will make you stand in the court,

74 ) in the midst of the assembled angels,

75) who are clad in fire, who do not give false judgement.

76) The devils will come,

77) they will proclaim your $\sin (\mathrm{s})$ :

78) "(He is the one) who used to swear (and) take oaths,

79) who used to take away people's cattle

80 ) and the wife of a young man who is not (even) away".

81) They will say about you: "This one deserves the Gehenna of fire".

82) Woe, they will have no mercy

83 ) on the day when the soul will wail,

84) woe, (his) father will not stand as (his)

attorney,

85) woe, there will be no mother (of his there),

86) woe, they will not appeal for (his) protection to the king where he sits on the throne of David.

87) You who have heard this (warning), be persistent in generosity,

88) give alms, ${ }^{58}$

89) do not swear, do not take oaths,

90) do not hoard gold in a sack; 59

91) (then) you will inherit the eternal kingdom of heaven.

92) Man, do not be unprepared -

93 ) illness will get the better of you.

94) This is what appeared to me, while I was not asleep. ${ }^{61}$

95) I believe in God the Father,

96) I believe in God the Son,

97) I believe in God the Holy Spirit -

98) three names, three persons, three faces, three images, one Lord;

58 Cf. Getatchew Haile 2005:260, verses 87-88.

59 Kane 1990: 782: $q^{\text {w } ə n n a m a t ~ " l e a t h e r ~ s a c k ~ o r ~ b a g ~ u s e d ~ f o r ~ c a r r y i n g ~ k n i v e s, ~ w r i t i n g ~ i m p l e-~}$

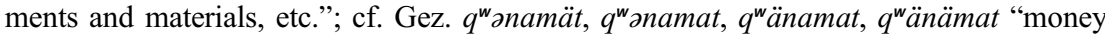
bag, purse" (Leslau 1987: 434).

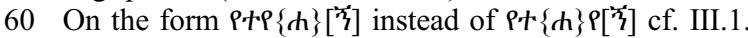

61 An alternative interpretation implies a different division into verses, with emendation of

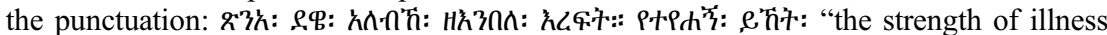
will be against you incessantly (without interruption). This is what appeared to me." 


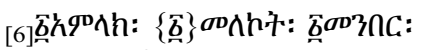

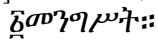

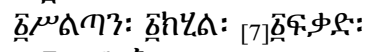

byqD Lit:

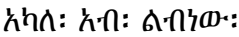

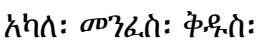

$[8]$ के, $, \omega \omega+4 \omega \cdot:$

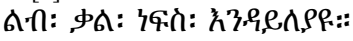

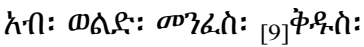
h,, , PP.qD:

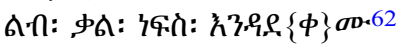

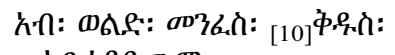

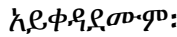

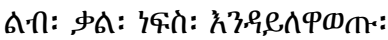

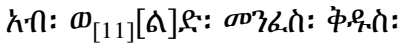
h, $е \wedge \varphi \omega_{\text {n.व. }}$

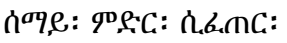

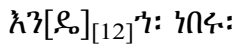

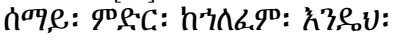

eisk:

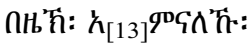

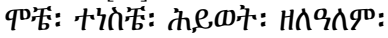

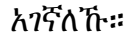

99) one God, one divinity, one throne, one kingdom;

100) one authority, one power, one intention, one will.

101) The person of the Father is heart,

102) the person of the Holy Spirit is life.

103) Just as heart, word and soul are inseparable, 104) so are the Father, the Son and the Holy Spirit inseparable.

105) Just as heart, word and soul do not compete with each other,

106) so the Father, the Son and the Holy Spirit do not compete with each other.

107) Just as heart, word and soul do not alter,

108) so the Father, the Son and the Holy Spirit do not alter.

109) They were like this when heaven and earth were created,

110) they will be like this after heaven and earth are gone.

111) I believe in this. ${ }^{63}$

112) Having died and risen, I will find eternal life.

\section{Orthography and language of the poem}

The text under scrutiny is characterized by a number of peculiarities. While some of these are to be discarded as scribal errors, others are to be explained in terms of palaeographic or orthographic variation, and still others reflect the phonological, morphological and syntactic features of Old Amharic.

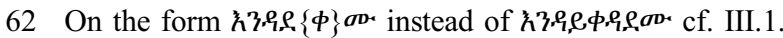

63 Verses 95-111 are a concise presentation of the doctrine of the Trinity in Amharic. Concerning verses $101-8$, we can find similar equations involving the members of the Trinity, e.g., in the "Confession of Jacob Baradaeus", cf. Cornill 1876: 421, esp. ' $h$ :

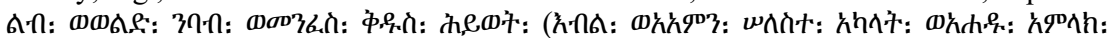

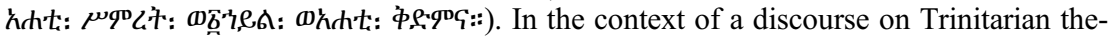
ology the term 'akal is conventionally rendered as "person"; the term mänbär (verse 99) does not seem to be typical. The well-known Amharic treatise 'Ammastu' a' madä masțir explains that 'akal (person), gäs (face) and mälk (image) are perfect and distinct for each member of the Trinity; as to the "person", the treatise explains that "akal is (everything) "from the hair of the head to the toenails" (cf. 'Ammastu "a madä mastir 1952 Am: 12-3; on the terminology, see Ayala Takla-Hāymānot 1974: 117-30). MärKL speaks about the "person" only for two members of the Trinity. Contemporary theologians of the Ethiopian Orthodox Church employ the term 'astanfas (breath) and not haywät, e.g., Habtä Maryam Wärqənäh 1963 Am: 61-6=3 (drawing upon Geez works, in particular the compendium Haymanotä 'abäw, stressing the co-equality of all members of the Trinity). The formula employed in MärKL appears incomplete and deficient, perhaps as a result of mistakes and text corruption, or because of difficulties in the exact Amharic wording of the theological concepts, or perhaps because it represented a kind of local theological stance. 


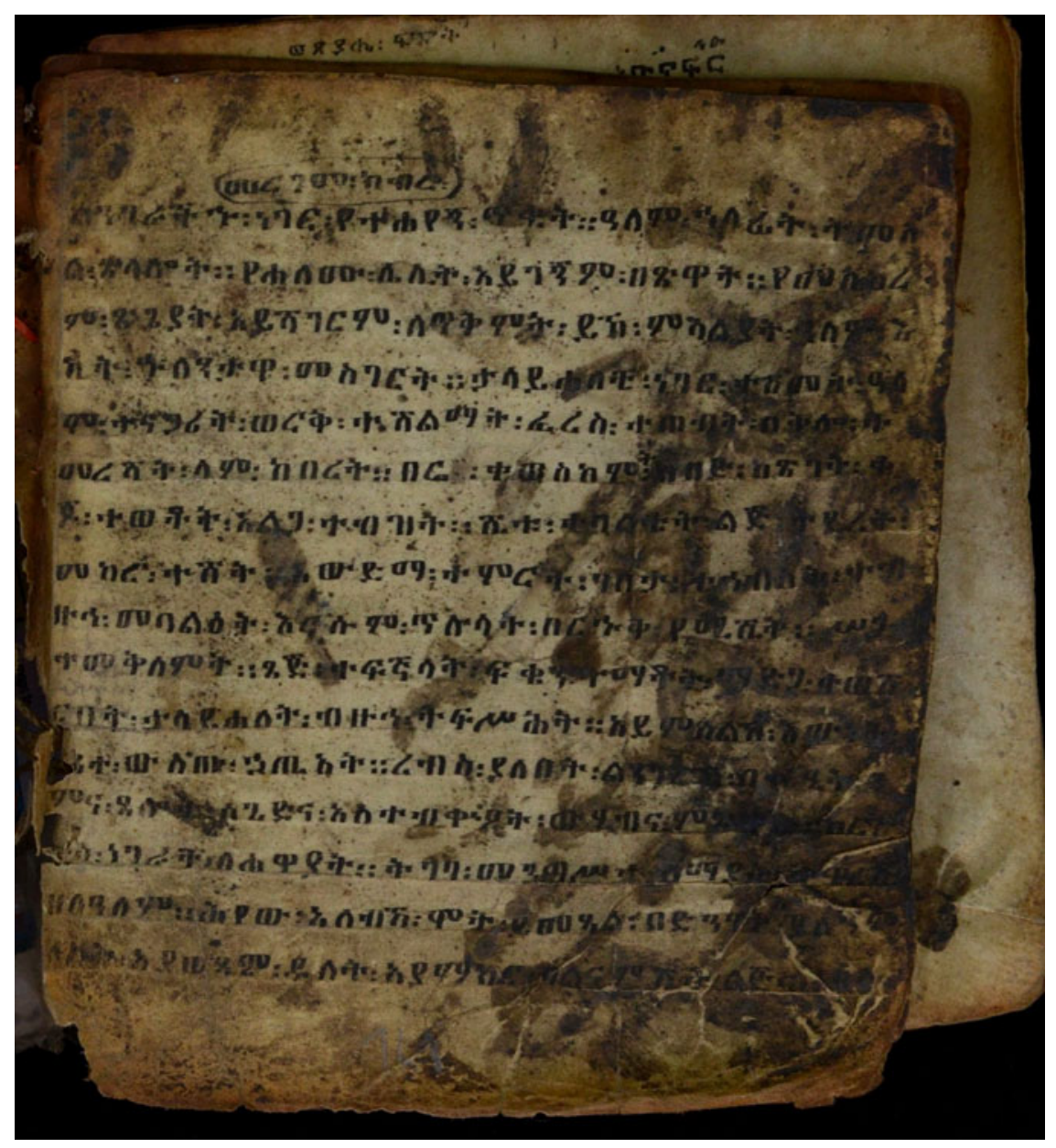

Figure 2. (Colour online) MS MKL-008, Läq̆ay Kidanä Məḥrät (Ethiopia), f. 141r [Märgämä kabr]

\section{III.1. Scribal errors}

The text contains a number of obvious scribal errors and faulty corrections made in

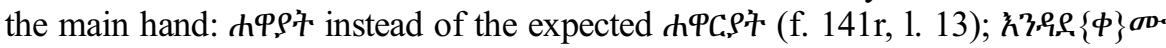

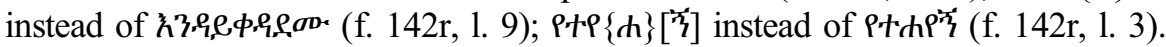

Some further cases are less clear since in principle they may reflect peculiarities of Old Amharic or be the result of palaeographic idiosyncrasies of the scribe.

In f. $141 \mathrm{r}, 1.9$, the third order of $\bar{\alpha}$ in the form par'in (instead of the expected paquit) may be the result of erroneous repetition of the third order marker of ${ }^{a}$. (but cf. III.6.3).

In f. 141r, 1. 14, one finds the form 376 instead of the expected 716.

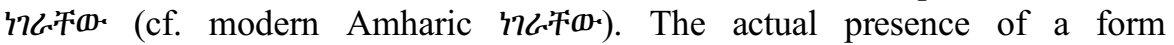

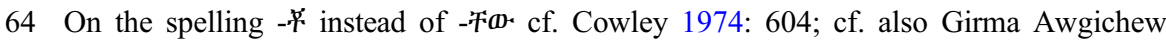
Demeke 2014: 117-8. 


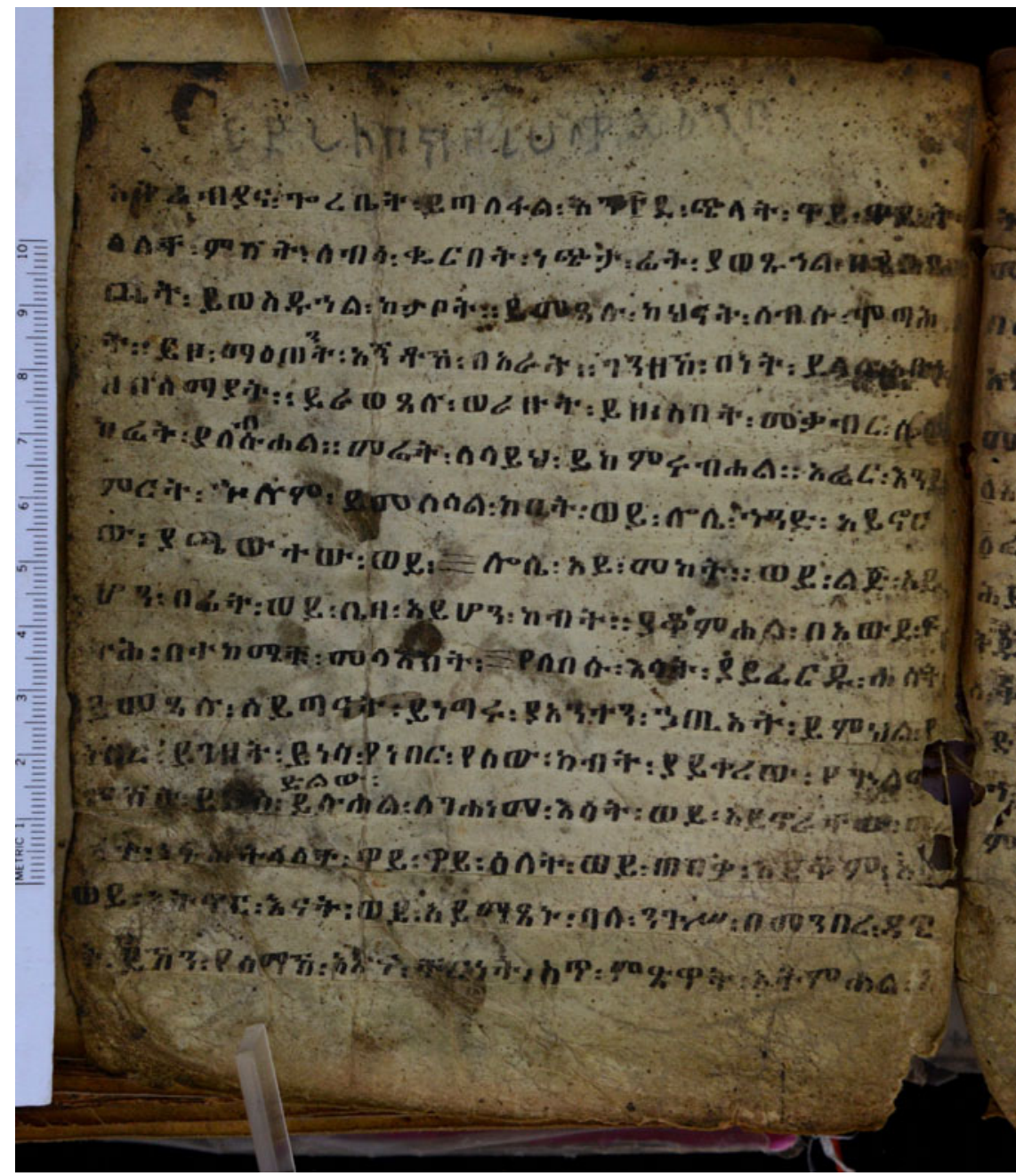

Figure 3. (Colour online) MS MKL-008, Läq̆ay Kidanä Məḥrät (Ethiopia), f. 141v [Märgämä kabr]

hercrfa-in the text (f. 141v, 1. 13) suggests that the 3 pl. object index was spelled as $-a^{2} \omega^{2}$ - in this text, and that the final $\omega^{-}$in the form under scrutiny was omitted through negligence.

Finally, in f. 141r, 1. 11, the form , Fi, ehn' appears instead of the expected P久, (Pi,ehn't) clearly shows palatalization of the final consonant. Thus, the absence of palatalization in f. 141r, 1. 11 is likely due to scribal error.

\section{III.2. Orthographic and palaeographic peculiarities}

\section{III.2.1. $h$ and $h$, 'h and $h$}

The kink which marks the sixth order in $h$ and $\mathrm{h}$ is not always easy to discern (see above, n. 25, on the same phenomenon in the main text of the manuscript). Note especially the form of $h$ in the words h, 


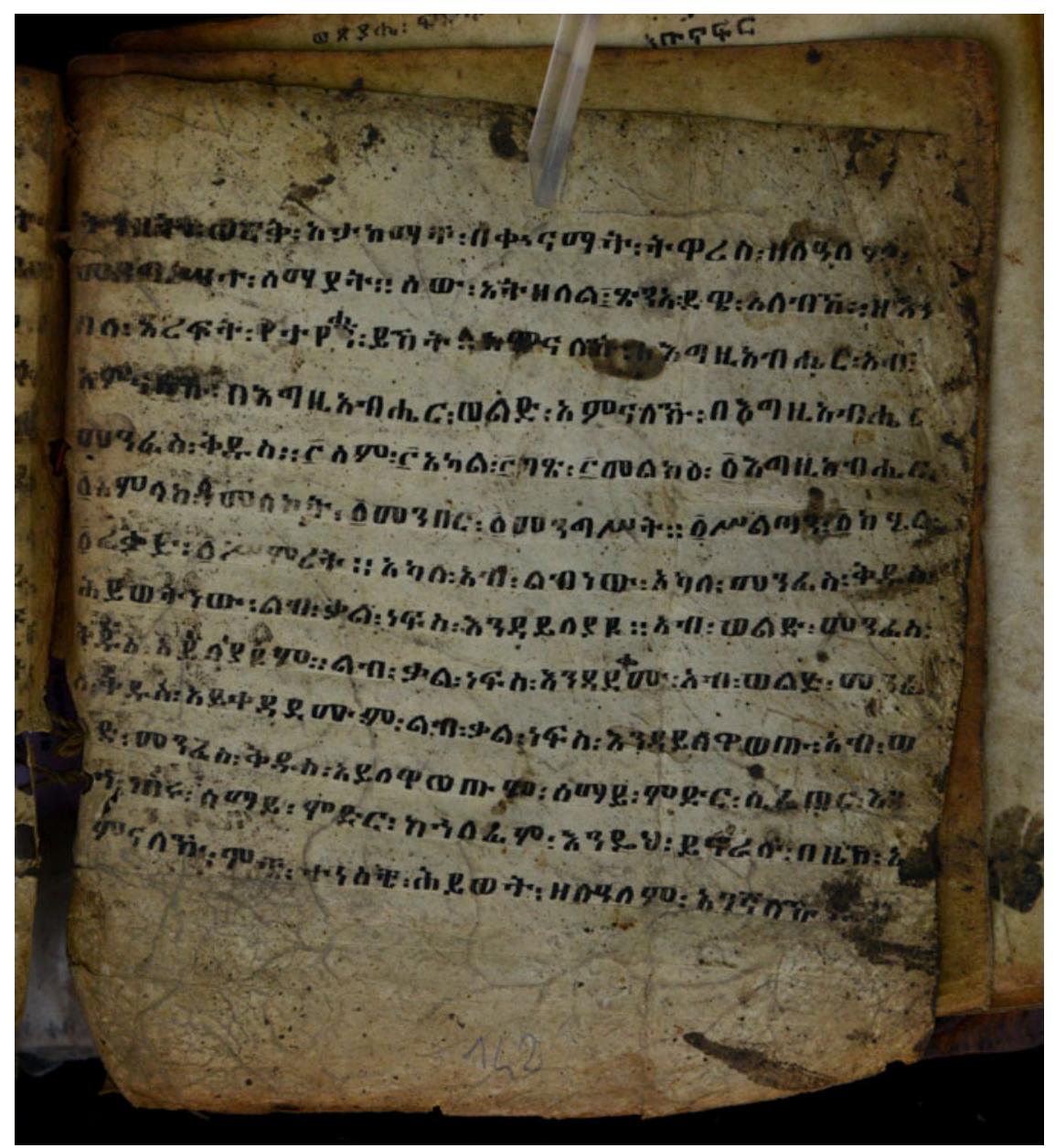

Figure 4. (Colour online) MS MKL-008, Läq̆ay Kidanä Məḥrät (Ethiopia), f. 142r [Märgämä kabr]

142r, 1. 6); cf. also hcitrin (f. 141r, 11. 13-4), where, however, the entire word, including the first letter, is hardly discernible. Likewise, the kink of ' $\mathrm{h}$ in $0 \mathrm{H}^{\prime} \mathrm{t}$ in f. 142 r, 1.12 is difficult to descry.

In the $2 \mathrm{sg}$. masc. subject and object index and in the sg. masc. demonstrative, no kink is discernible at all, and consequently, the reading ' $\mathrm{h}$ has been preferred (cf. III.4.1, III.4.3).

\section{III.2.2. "7 and '7}

A distinct ' 7 occurs twice (f. 141r, 1. 9, 1. 11) and has the classical shape (the vertical stem with a kink - graphically nothing but $\xi[n \ddot{a}]$ - and a short curved line above, directed to the left, downwards).

MärKL contains two words in which the first order of the letter apparently stands for the sixth order: f. 141r, 1.8 ("7nd' instead of the expected 'tnh't), f.

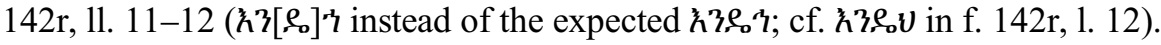




\section{III.2.3. 年 instead of 管}

A distinct + appears in the very first line of the text. Having the form of the sign i with a dash above, it differs clearly from the first order 7 . Yet in three cases 7 is attested instead of the expected

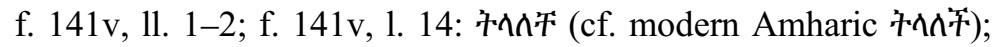

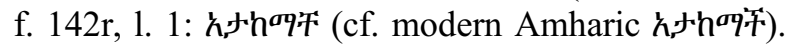

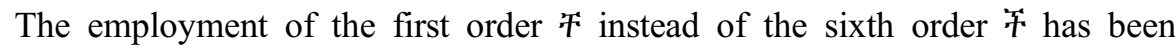
observed in other Old Amharic texts (Geta[t]chew Haile 1969-70: 70, n. 10; Strelcyn 1981: 73; cf. also Cowley 1974: 602, where it is noted that and 7 are barely distinguished in the text).

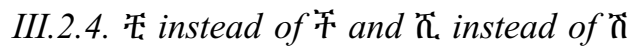

There is one example of employed instead of 2 , and one clear example of $\bar{\lambda}$. instead of ñ:

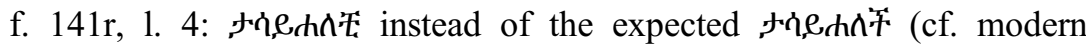
Amharic , गh,

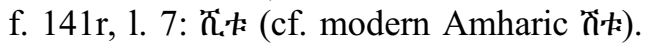

Such use of t $^{2}$ and (as well as the use of the third order instead of the sixth order for some other palatal consonants) is well attested in Old Amharic texts (cf. Getatchew Haile 1979a: 234; 1983: 158; Strelcyn 1981: 73).

\section{III.2.5. Separate writing of some particles or prefixes}

As already noted in editions of other Old Amharic texts, some particles and affixes can be written as separate words in Old Amharic, unlike modern Amharic (cf. e.g. Richter 1997: 550, Strelcyn 1981: 74). In the present text, the relevant example is f. $141 \mathrm{v}, 1.8$ : h,e: adh' (cf. modern Amharic h,eaph').

\section{III.2.6. Writing of the copula $4 \omega \cdot$ joined to the preceding word}

The copula $4 \omega^{*}$ frequently appears joined to the preceding word in Old Amharic writings (cf. Getatchew Haile 1979b: 121; Cowley 1983b: 25; 1974: 604). In the present text, this phenomenon is found in f. $142 \mathrm{r}, 1.7 ; 1.8$.

\section{III.3. Phonetic phenomena ${ }^{65}$}

\section{III.3.1. Preservation of the gutturals}

It is well known that Old Amharic texts contain numerous examples of preservation of historical gutturals which have been lost in modern Amharic (cf. Getatchew Haile 1979a: 234; Strelcyn 1981: 75; Appleyard 2003: 114; Getatchew Haile 1991: 529; Richter 1997: 548; Strelcyn 1964: 108-9; Girma Awgichew Demeke 2014: 24-34).

Various texts show various degrees of loss of historical gutturals. Notably, R. Cowley observes that in the so-called Tract about Mary Who Anointed Jesus'

65 This section deals with Amharic lexemes and word-forms. Obvious Geez loanwords and Geez insertions (cf. III.7) are not treated here. 
Feet and in Tomhrrtä Haymanot, the reflexes of *' and *' are dropped wordmedially and sometimes word-finally, while the reflexes of $* h, * h$, and $* h$ are spelled out in all positions in the word (Cowley 1974: 605-6; 1983b: 21).

The spellings attested in MärKL are in the same line as those of the texts edited by Cowley. MärKL shows consistent omission of etymological *' and *' word-internally and word-finally: eלd (f. 141v, 1. 12; cf. Gez. näśs $a$, Leslau 1987: 404), +7ר (f. 141r, 1. 14), eavod (f. 141r, 1. 15), eavok (f. 141v, 1. 3; 1.

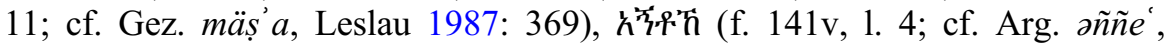
Girma Awgichew Demeke 2013: 227; for comparable forms in Old Amharic and other South Ethio-Semitic languages cf. Bulakh and Kogan 2016: 285-6),

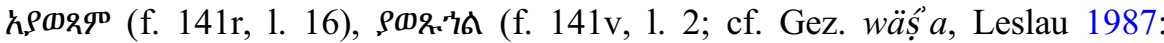

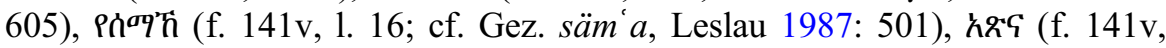
1. 16; cf. Gez. 'așnə'a, Leslau 1987: 559), nढ (f. 141r, 1. 6; cf. Gez. bə ray,

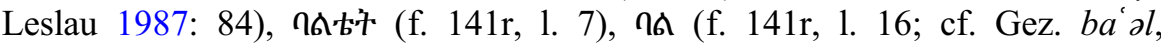
bä́al, ba' alt, Leslau 1987: 84).

At the same time, word-initial $h$ seems to be preserved when preceded by a proclitic (a similar tendency has been observed in several editions of Old Amharic texts; cf. Cowley 1974: 603; Strelcyn 1981: 74):

\section{f. 141v, 1. 11: $943+3$ (cf. modern Amharic $93+3$ ).}

Note that the spelling $P_{h}^{\prime} 3+3$ does not reflect the underlying form $\{$ yä-antä-n\}, but rather is the result of vowel assimilation across the guttural: *y $\ddot{a}$-' ant $\ddot{a}-n>$

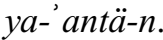

Note also the form nhlst in f. 141v, 1. 4, where, however, the preservation of $h$ at least in the written form is characteristic of modern Amharic as well.

As for the distinction between word-initial $h$ and 0 , in Amharic words the spelling with ' $h$ seems to be preferred even in cases of historical ${ }^{*}:\left[\lambda^{\prime}\right] \mathbf{3}$ ' (f. 141v, 11. 2-3; cf. Leslau 1987: 57), h6.c (f. 141v, 1. 6; cf. Bulakh and Kogan 2016: 152-3); cf. also חhsi (f. 141v, 1. 4; cf. Leslau 1987: 71). This implies that no distinction between ' and ' existed at the time of the creation of the copy, the above-mentioned words being pronounced either with initial or with no initial consonant.

The text shows interchangeability between $v$ and $h$ (as in the verb "to swear":

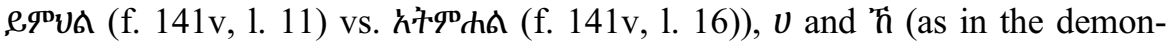
strative pronoun, cf. III.4.3), $v$ and $" z$ (as in the adverbial "like this": $\lambda ?\left[\ell_{0}\right] " z$,

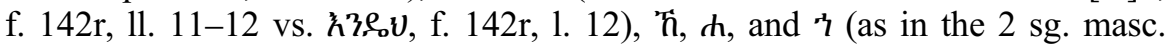
subject and object indexes, cf. III.4.1). It is therefore unlikely that these graphemes represent different phonemes; in all probability, by the time this copy was produced, the merger of $* h, * h$, and $* h$ into a single phoneme (transcribed here with $h$, as in modern Amharic) had been completed.

This single phoneme $h$, rendered by $v$, $\boldsymbol{~ h , ~} \bar{h}$ or $h$, is often present where expected on etymological grounds (going back to $* h$, *h or $* h$ ), even where it has been lost in modern Amharic. This involves the following roots and lexemes:

1) The forms of the verb "to see" ( $h \rho$ in modern Amharic, going back to *hzy, cf. Leslau 1979: 123; the spelling with $h$ is well-attested in Old Amharic, 
cf., e.g., Littmann 1943: 484) and its passive stem: hPa- (f. 141r, 1. 15), Prop stem, cf. below.

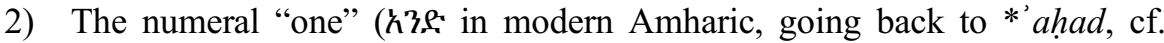
Leslau 1987: 12; for the spelling 23 . Haile 1979b: 122): 't3. (f. 141v, 1. 7).

3) The forms of the verb "to swear" (

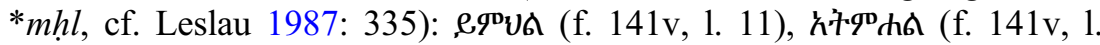
16). Note that in this case, the influence of Gez. mähalä is not to be excluded.

4) The verb "to dream" ( $h \Lambda^{\sigma D}$ in modern Amharic, going back to *hlm, cf.

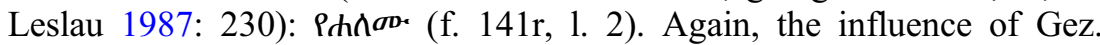
halämä can well be imagined.

5) The verb "to pass" (' $\Lambda$ ) 6 in modern Amharic, going back to *hlf, cf. Leslau 1987: 260-1): 'h`h6.9D (f. 142r, 1. 12). The influence of Gez. haläfä is likely.

6) The adjective "far" ( $\zeta \dot{\phi}$ in modern Amharic, going back to * rhq, cf. Leslau

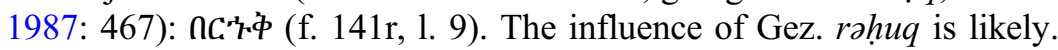

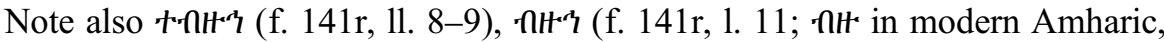
going back to $* b z h$, cf. Leslau 1987: 117), which, however, in both contexts is followed by a Geez lexeme and can itself be a Geez insertion (cf. III.7).

At the same time, the text contains five certain cases of lost $* h, * h$ or $* h$ (despite the existence of Geez equivalents containing the guttural): ${ }^{66}$

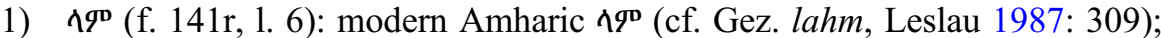

2) h, Leslau 1987: 335);

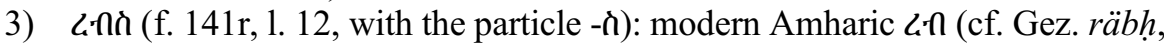
Leslau 1987: 461);

4)

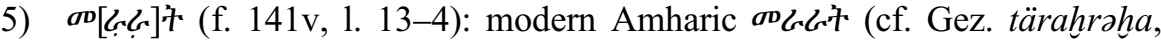
Leslau 1987: 468),

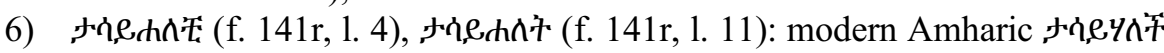
(cf. the forms of the verb "to see" with the initial guttural quoted above).

Thus, the evidence for preservation/loss of $h$ in the text is inconsistent. One may suspect that the examples of the preserved gutturals are due to archaic orthography (which may have been in use not only for lexemes having transparent Geez counterparts, but also for the specifically Old Amharic forms of the verb "to see" and of the numeral "one") and do not reflect the actual pronunciation.

\section{III.3.2. Preservation of ejective affricate $\mathbf{s}$}

A well-known feature of Old Amharic is the preservation of affricate $s$, which in modern standard Amharic has mostly shifted to plosive $t$ (cf. Getatchew Haile 1979a: 234; 1983: 161-2; 1991: 528; Appleyard 2003: 115; Cowley 1974:

66 A much less reliable case is din in f. $141 \mathrm{v}, 1.5$ (cf. III.6.7), which can be tentatively related to the root *shb 'to pull, to draw" (for which cf. Leslau 1987: 492-3). 
603; Richter 1997: 548; Strelcyn 1964: 109-10; 1981: 75; Podolsky 1991: 22-3; Girma Awgichew Demeke 2014: 34-7; cf. also Strelcyn 1968). In the text under survey, this phenomenon is observed in the following cases:

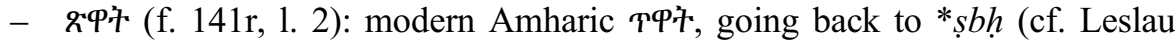
1987: 545; for the Old Amharic spelling gn', g.中⿰冫 cf. Ludolf 1698: 97);

- g'午 (f. 141r, 1. 6): modern Amharic T7\%; the Geez form saggät, adduced in Leslau 1987: 550, but absent from Dillmann 1865, is probably an Amharism appearing in post-Aksumite texts;

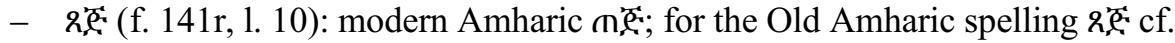
Ludolf 1698: 98, Strelcyn 1981: 75;

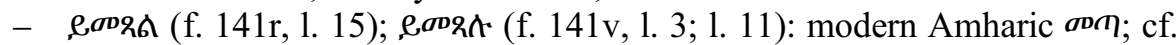
Gez. mäș’a (Leslau 1987: 369);

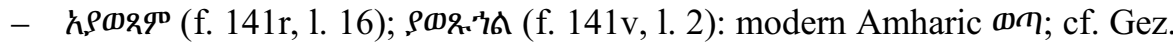
wäș’́a (Leslau 1987: 605);

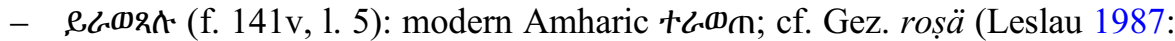
477);

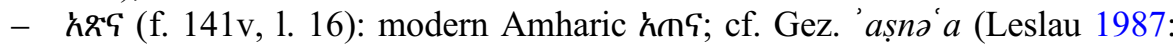
$559)$;

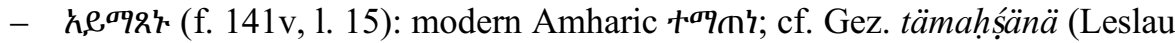
1987: 335).

\section{III.3.3. Spirantization}

Podolsky (1991: 32-3) has convincingly demonstrated that spirantization $k>h$ was more widespread in Old Amharic than it is in the modern language (cf. also Girma Awgichew Demeke 2014: 13, 49 ff.). In the text under scrutiny, however, no examples of spirantization have been detected except for those forms which have entered modern Amharic as well:

2 sg. (cf. III.4.1) and pl. (as in f. 141r, 1. 1) subject and object indexes (the elements $-h \ddot{a}$ and $-h u$ go back to proto-Ethio-Semitic *-ka and *-kum, respectively);

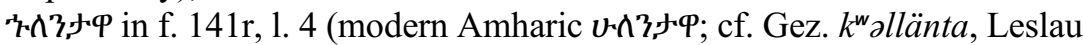
1987: 281) and 'r.9p in f. 141v, 1.7 (modern Amharic v $\mathbf{k} \mathbf{q}$; cf. Gez. $k^{w}$ allu, ibid.).

\section{III.4. Morphology}

III.4.1. The 2 sg. masc. suffix

Word-finally, the $2 \mathrm{sg}$. masc. object index and the $2 \mathrm{sg}$. masc. subject index appear as $-\mathrm{n} n$ in all the attested occurrences listed below:

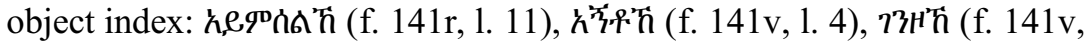

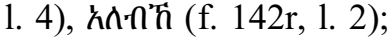

subject index: $\varphi^{\sigma \sigma} \mathrm{T}$ (f. $141 \mathrm{v}, 1.16$ ).

These forms contrast with the vowelless ending $-\boldsymbol{v}$ of modern Amharic. The only attestation of $-v$ in the text under scrutiny is $n \lambda, e v$ in $f .141 \mathrm{v}, 1$. 6 . There is, however, no reason to believe that the shape of the $2 \mathrm{sg}$. masc. index attached to the 
preposition was different from the $2 \mathrm{sg}$. masc. subject and object indexes, since such an opposition is not known from any Ethio-Semitic language. Rather, we are dealing with two alternative forms of the $2 \mathrm{sg}$. masc. suffix.

Examples of word-final $2 \mathrm{sg}$. masc. object index and $2 \mathrm{sg}$. masc. subject index - $\mathrm{t}$ in Old Amharic are found in several pieces of Old Amharic poetry published by Getatchew Haile (1991: 527). Since the modern Amharic - $h$ must go back to $*_{-} k a>*_{-} k \ddot{a}$ (with subsequent spirantization and loss of the final vowel), the form -hä (rendered by ' $\tilde{h}$ ) is a plausible predecessor of the modern Amharic form.

\section{III.4.2. The 3 sg. masc. object index}

In the form heica- (f. 141v, 11. 7-8), the $3 \mathrm{sg}$. masc. object index attached to the imperfect base is ${ }_{-} \omega^{*}$, rather than the modern Amharic - $\ddot{a} \omega^{*}$ (note, however, that

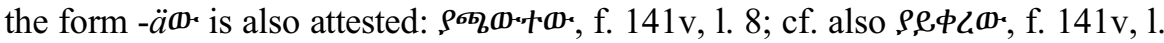
12; cf. also - $\ddot{a} \omega^{*}$ with imperative base in $\dot{\phi} \rho \omega^{*}$, f. 141r, 1. 15).

The $3 \mathrm{sg}$. masc. object index - $-2 \omega^{*}$ attached to the verb 'hi' 7 (but not to other verbs in Getatchew's text) was recorded in Getatchew Haile 1986: 235 (alongside the 1 pl. object index $-\partial$ ). While Getatchew Haile tends to ascribe these forms to the graphic confusion between ' $\bar{r}$ and $\vec{\xi}$, the existence of a parallel in MärKL suggests rather a genuine morphological feature of Old Amharic.

\section{III.4.3. Demonstrative pronouns}

The text contains the following forms of the $3 \mathrm{sg}$. masc. independent demonstrative pronoun, once as a bare form, and three times with three different enclitics:

f. 141r, 1. 3:, e'n;

f. $141 \mathrm{v}, 1.13:, e[v] \AA$ (with contrastive $-\grave{c})$;

f. $141 \mathrm{v}, 1.16:, e$ 'ก 3 (with accusative marker -3 );

f. 142r, 1. 3: e'n't (with the post-pronominal element -7, cf. III.5.3).

The spelling,$e[v] \AA$, where $v$, although not quite clear, is still discernible under the blot, indicates that we are dealing with a form identical to,$v v$ in modern Amharic. The form yahä, which occurs in the rest of the attestations, finds parallels both in modern Amharic (mostly before suffixes and enclitics, cf. Leslau 1995: 62-3, but cf. also Girma Awgichew Demeke 2014: 194, 199) and in an Old Amharic text published by Getatchew Haile (1986: 239, example 4.1.c.: e'ni,,$e+\hbar$; note that in both cases, the vowel $\ddot{a}$ appears before an enclitic).

The combination of the demonstrative with a preposition clearly lacks a final vowel: nH't (f. 142r, 1. 12).

The element -zzeh (contrasting -zzih in modern Amharic) finds an exact correspondent in several other Old Amharic texts (cf. Appleyard 2003: 115: hbv,

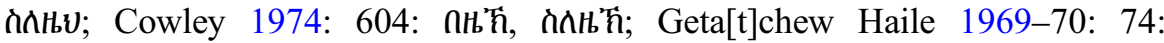
え30กҢ丸; cf. Girma Awgichew Demeke 2014: 196).

\section{III.4.4. 3 pl. of converb}

The text contains several converb forms in which the marking for 3 plural is expected, but which exhibit the ending $-o$ or, once, $-u$ : 
กคดk (f. 141v, 1. 3);

e.H (f. $141 \mathrm{v}, 1.4 ; 1.5)$;

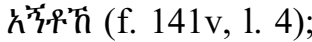

$73 \mu^{2} \pi$ (f. $\left.141 \mathrm{v}, 1.4\right)$.

As Goldenberg points out (2017: 553, n. 1), the apparent absence of number agreement results from contraction $\ddot{a} w>o$ (in $\lambda \cdot \hat{n} \dot{k}$, sporadically shifting to $-u$ ), ${ }^{67}$ otherwise attested in Old Amharic in the 3 pl. object index (on which cf. Cowley 1974: 603, 604).

This phenomenon is known from other Old Amharic texts, e.g. Getatchew

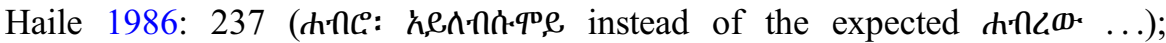

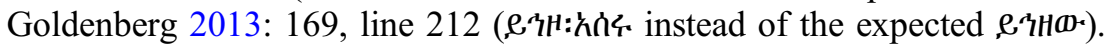

\section{III.4.5. Negative imperfect in the main clause}

Of the 16 examples of negative imperfect forms in the main clause, seven have the element $\mathbf{- q \mathbf { p }}$, obligatory in modern Amharic:

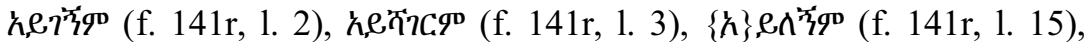

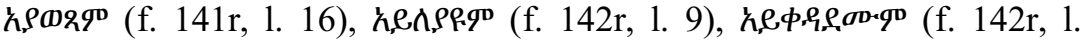

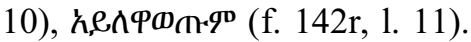

The remaining forms represent prefixal negation without the element $\mathbf{- q D}$ :

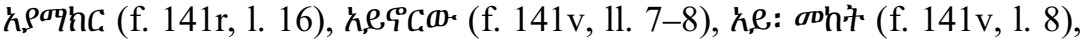
h,

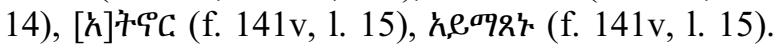

Negated main verbs without the element $\mathbf{- q D}$ are found in other Old Amharic texts (cf. Girma Awgichew Demeke 2014: 132-3; for an additional example

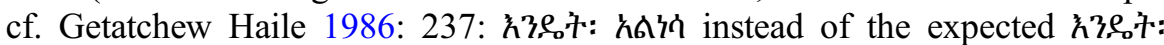

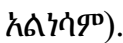

\section{III.4.6. Relative imperfect (positive and negative)}

The prefix yämm(ว)- (in modern Amharic the only marker of relative imperfect) is attested once: paquit (f. 141r, 1. 9). An example of simple imperfect, unexpanded by any special relative marker, is found in the syntactic position of a

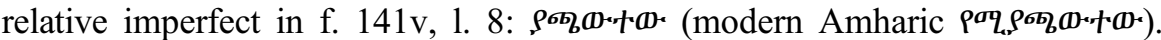
Similar usage of simple imperfect is known from other Old Amharic texts (cf. Cowley 1983b: 23; Getatchew Haile 1983: 163; Goldenberg 1977: 488).

The text contains two examples of negative imperfect in the relative clause:

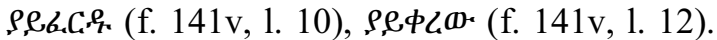

67 Since the ending - $o$ with converb is normally the $3 \mathrm{sg}$. masc. subject index, the shift to $-u$ (be it phonological, graphical, or merely a scribal emendation) may represent an attempt to avoid the homophony. 
In both forms, the negative prefix is attached to the relative prefix $y \ddot{a}$ - (rather than to yämm-, as in modern Amharic). This same negative relative imperfect form is known from other Old Amharic texts (cf. Geta[t]chew Haile 1969-70: 79-80; 1979a: 235; 1979b: 121; Appleyard 2003: 115; Cowley 1974: 605; 1977: 139, 142; Goldenberg 1977: 488; Girma Awgichew Demeke 2014: 145-6).

The text under scrutiny also contains three examples of negative imperfect following the conjunction ${ }^{2} 3$, "just as, like". In all these examples, the relative marker is absent:

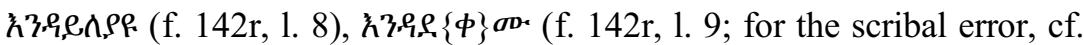

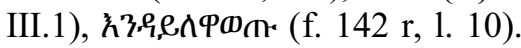

In modern Amharic, relative imperfect is demanded in this construction (Leslau 1995: 701-2). For Old Amharic, lack of relative marker after $\hbar 3:$. has been observed by Cowley (1977: 141; an obviously related phenomenon is lack of relative marker after the conjunction h, cf. Cowley 1977: 141; Getatchew Haile 1983: 163).

\section{III.4.7. Frequentative stems}

Some Old Amharic texts are characterized by lack or extreme rarity of frequentative stems (Strelcyn 1964: 110; 1981: 77). It is therefore worth observing that the text under scrutiny contains three frequentative verbs (each of them employed twice):

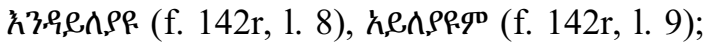

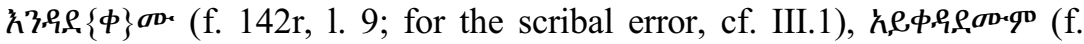

142r, 1. 10);

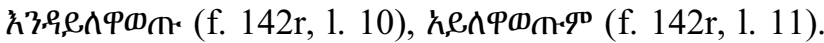

\section{III.4.8. Prepositions}

In the sequence of paired nouns on $\mathrm{f} .141 \mathrm{r}, 11.4-11$, the comitative preposition is mostly + -; only twice is $h$ - employed with the same function.

There is one example of the ablative preposition h- (f. 141v, 1. 7). Besides, his once used with the meaning "towards" (f. 141v, 1. 3), which likewise finds parallels elsewhere in Old Amharic (Appleyard 2003: 115).

The semantic opposition between the comitative + - and directional $h$ - was observed by F. Praetorius (1879: 401). However, in the modern language + has become a variant of $\mathrm{h}$ - (cf. Leslau 1995: 605, 706 with n. 1; on the dialectal distribution cf. Zelealem Leyew 2007: 455). In at least some Old Amharic texts, the semantic distinction between $\boldsymbol{t}$ - and $\mathrm{h}$ - is quite prominent, with only sporadic encroachment of one on the other's domain. This is true of the "Royal Songs" (cf. Littmann 1943: 483, 489, 493), Tamhartä haymanot (Cowley 1974 , cf. e.g. ablative $\mathrm{h}$ - in $10 \mathrm{v}$, lines 1,4 vs. comitative + - in $12 \mathrm{v}$, lines $5-$ 6) and Mośtirä șgeyat (Goldenberg 2013, cf. e.g. ablative h- in lines 23-4 vs. comitative $t$ - in lines 27-30). In the discussion of $t-$ and $h$ - in Old 
Amharic, the semantic aspect is usually ignored, as in Cowley 1974: 605, Richter 1997: 550, Girma Awgichew Demeke 2014: $86 .{ }^{68}$

Several authors have observed the employment of the Geez preposition "without" in Old Amharic instead of the Amharic Pᄉ (cf. Getatchew Haile 1983: 163; Appleyard 2003: 115; Cowley 1974: 606-7). In the present text, too, Geez Hìn appears in f. 142r, 11. 2-3 in this function (admittedly, the whole phrase

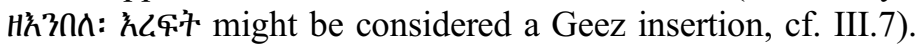

\section{III.5. Syntax}

III.5.1. Simple and compound imperfect in the main clause

The text contains two instances of simple imperfect in the main sentence:

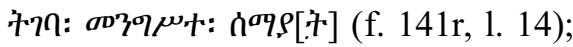

องๆद:

Less certain are three other cases, where the whole phrases may be Geez insertions (cf. III.7):

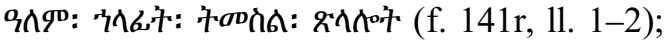

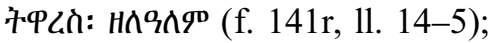

+中

At the same time, the text contains 17 examples of compound imperfect: 小h, ,

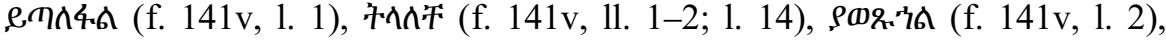

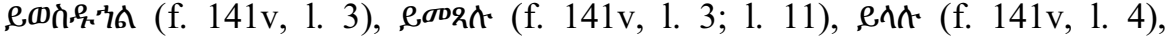

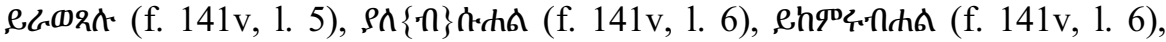

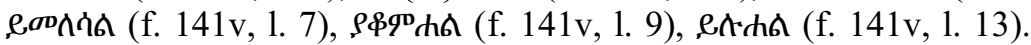

Forms of the imperfect without auxiliary in main clauses are found in other Old Amharic texts (cf. Girma Awgichew Demeke 2014: 126-7). In the "Royal Songs" they are well attested, while the compound imperfect is absent (Richter 1997: 550). In most other texts one encounters both simple imperfect and compound forms in main clauses (cf. Cowley 1983b: 25; Getatchew Haile 1980: 579; Strelcyn 1981: 80; Girma Awgichew Demeke 2014: 128).

\section{III.5.2. Agreement}

In Getatchew Haile 1986: 236, lack of number agreement is mentioned as a specific Old Amharic feature. In two of three examples quoted by Getatchew Haile, the verb is marked as singular while its subject is represented by two coordinate nouns. In the text under scrutiny, this phenomenon can be observed in the following two phrases:

68 According to Girma Awgichew Demeke (2014: 86), “... the distribution of $t \ddot{a}$ seems very limited in $\mathrm{O}[\mathrm{ld}] \mathrm{A}[\mathrm{mharic}] "$. This is certainly an underestimation: $\boldsymbol{t}$ - occurs six times in the "Royal Songs" and no fewer than 11 times in Tomhorta haymanot. 


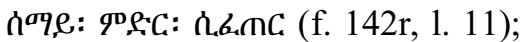

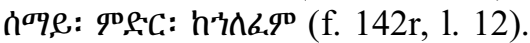

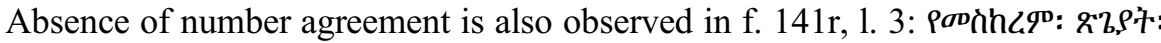

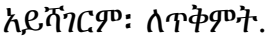

\section{III.5.3. Post-pronominal - 7}

One of the most interesting features of Old Amharic is the employment of the element - 7 , absent from modern Amharic. This element, appearing after independent pronouns, demonstrative pronouns, and pronominal suffixes, was discovered and examined by Goldenberg, who analysed it as a copula (Goldenberg 1974: 247; 1976; cf. also Cowley 1977; 1983a: 24-5; 1983b: 25, 31-3). For criticism of this analysis cf. Getatchew Haile 1979b: 119-21; 1983: 167-8; 1986: 238-40. The element -7 is plausibly interpreted as a focus marker in Crass et al. 2005: 30 and Girma Awgichew Demeke 2014: 180-9.

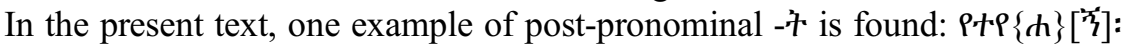

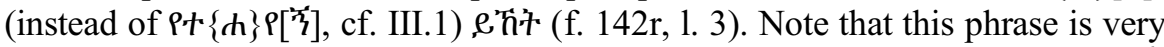
similar to one of the examples adduced in Goldenberg 1974: 247 ( e'n't).

\section{III.5.4. Word order}

The rigid left-branching syntax of modern Amharic is not characteristic for the text under scrutiny. One finds quite a few clear examples of right-branching order (well attested for Old Amharic, cf. Girma Awgichew Demeke 2014: 138-44):

- Verb - Subject (Фe: $141 \mathrm{v}, 1.3$; els

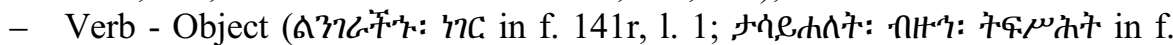
141r, 1. 11; etc.);

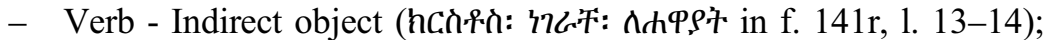

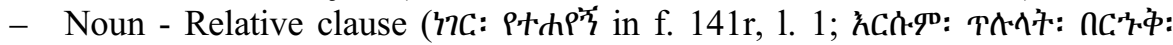
parâ, in f. 141r, 1. 9).

Instances of left-branching word order are also present in the text. Note, for

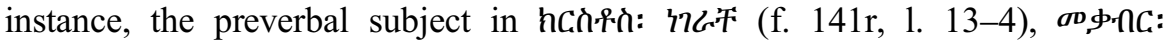

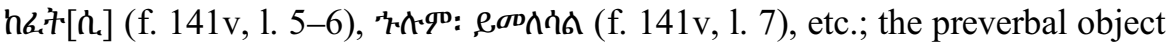

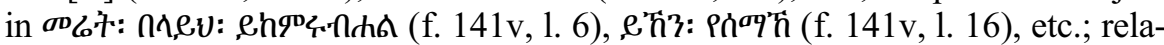

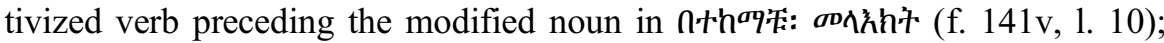
genitive modifier preceding the modifed noun in Piar: hon (f. $141 \mathrm{v}, 1.12$ )

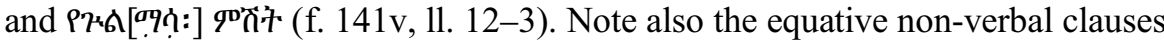
with the order Subject - Predicate - Copula in f. 142r, 11. 7-8.

\section{III.6. Vocabulary}

As expected, MärKL contains a number of lexemes absent or rarely used in modern Amharic, or divergent in form from their modern Amharic equivalents. Some of these can be found in sections III.3.1, III.3.2. Other lexemes from this text which are missing from Kane 1990 or divergent from the forms attested there are listed below. 


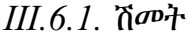

The form Top appears once in the text (f. 141r, 1. 4) instead of the expected

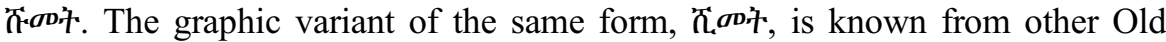

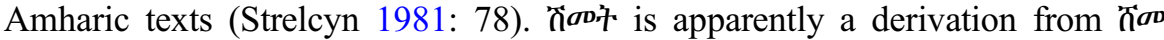
"appoint", a direct correspondent of Gez. śemä "appoint" (śimät "office", Leslau 1987: 539-40; cf. also Tna. šamät/šimät “office”, Kane 2000: 865).

On the passive stem from the same root, $\boldsymbol{W h}^{\boldsymbol{\sigma} \boldsymbol{D}}$, attested in another Old Amharic text, see Appleyard 2003: 115 (where modern Amharic "iकo i "office,

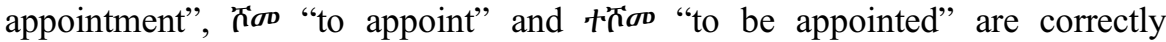
explained as back-formations from $\bar{k} \mathbf{q})$.

\section{III.6.2. D. 许}

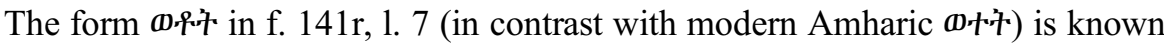
from other Old Amharic sources (cf. Ludolf 1698: 72; Geta[t]chew Haile 196970: 76; Cowley 1974: 606; 1983a: 25; Bulakh and Kogan 2016: 222).

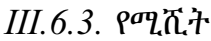

In f. 141r, 1. 9, the form pardit instead of the expected pardit (unless due to a scribal error, cf. III.1) seems to point to a specific Old Amharic verb Not (the

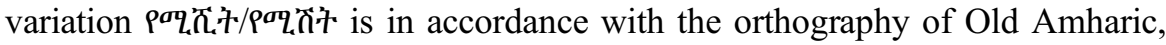
cf. III.2.4). The modern Amharic "it+ "to smell" is then a recent innovation. Its cognates in South Ethio-Semitic exhibit various extensions of $\check{s}$ - $t$, mostly via an additional vowel or laryngeal after $t$ (Čah. šäta, ヨnm. Gyt. šätāa, Eža Muh. šätta, And. šetta’a, Leslau 1979: 587). Note especially Gaf. šičä (Leslau 1956: 238), whose underlying form may be identical with that of the hypothetical Old Amharic $\mathfrak{T}+{ }^{69}$

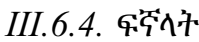

The word F'? is mentioned in Strelcyn 1981: 72, 1.1.1, although we could not find it in the Old Amharic text discussed by Strelcyn). The origin of this lexeme is probably to be sought in Gez. fayyalat, pl. of fayyal "vial, glass, bowl, cup" (Leslau 1987: 173; Dillmann 1865: 1377, < Gr. fiálēe). The phonetic aspect of this identification is, however, far from clear: the change $\tilde{n}>y$, attested in Amharic dialects of Wogera and Wollo (Zelealem Leyew 2007: 451, 454) as well as in an Old Amharic text (Cowley 1983b: 21), is apparently unidirectional. The form F'‘ $\wedge$ ' + may have emerged under the influence of fanğal "porcelain teacup or coffee cup" (Kane 1990: 2321, < Arb. finğān-, cf. Leslau 1990: 18; on its presence in Old Amharic cf. Strelcyn 1964: 263). Despite the semantic difference, folk etymology regards fanğal as the Amharic equivalent of Gez. fayyal (cf. Dästa Täklä Wäld 1962 AM: 985: fanğal... bägə’ əz foyyal yəbbalal "fonğal is called fayyal in Geez"; cf. also Dillmann 1865: 1377). The insertion of $n$ into fayyal under the influence of fanğal would lead to fanyal $>$ fañ $(\tilde{n}) a l$.

69 Further cognates, pointing towards medial -o- (some of them with insertion of $-n$-), are more distant from the above-mentioned forms (cf. Leslau 1997: 220; 1963: 137; 1979: $587,565,569)$. 


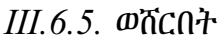

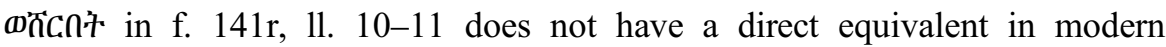
Amharic. The only comparable lexeme is rather remote in shape: mäšräb "large trough in which water or other liquid is kept..." (Kane 1990: 622, < Arb. mašrab-, Leslau 1990: 200). Yet an exact correspondent is found in Zay: wošärbät "kind of jar" (Leslau 1979: 669).

The Zay term may well be an early Amharism, ultimately going back to Arb. mišrabat- "cruchon en terre" (Biberstein Kazimirski 1860: 1211).

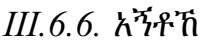

In f. $141 \mathrm{v}, 1.4$, the form $h^{2}{ }^{2} p^{2}$ appears, which is the 3 pl. (cf. III.4.4) converb (with the $2 \mathrm{sg}$. masc. object index) from the verb $h^{\prime} \bar{F}$ "to cause or to assist one to

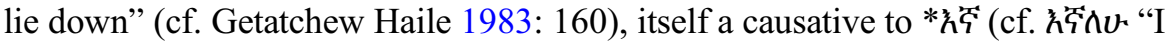
sleep", etc.) attested in Geta[t]chew Haile 1969-70: 71. On other Old Amharic attestations of this root, as well as on its cognates in other South Ethio-Semitic languages cf. Bulakh and Kogan 2016: 285-6.

\section{III.6.7. in}

The lexeme inn' in f. $141 \mathrm{v}, 1.5$ might be a derivative from the verb in "to draw, pull, pull tight" (Kane 1990: 513; however, the meaning "gravity, gravitation" adduced in Kane 1990: 514 for sabät hardly fits the present context). Possibly it relates to some technical details in the Ethiopian seventeenth-century funeral ritual (cf. the references in notes 53-4 and Pankhurst 1990: 196-9). Could inn in the present context refer to something like ropes (the method of transporting the dead body has been already referred to above, see verse 55; cf. traditional depiction of lowering the body, wrapped in a mat or cloth, into the grave by means of ropes, Chojnacki 1983: 324, fig. 144c)? Alternatively, the word can be seen as a derivative from säbbätä "to break the soil with the plough" (Kane 1990: 524; cf. also sabät "first furrow", ibid.), perhaps metaphorically referring to the instruments for digging the grave. Admittedly, both interpretations are highly speculative. A deeper historical study of the funeral practices of the Ethiopian Christian highlands might shed light on this passage, a task going beyond the scope of the article.

\section{III.7. Geez insertions}

As is usual with Old Amharic compositions, the text under scrutiny is interspersed with Geez lexemes, collocations and phrases. The distinction between

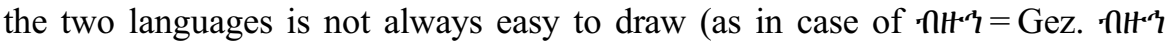

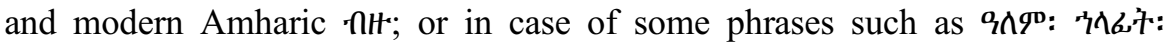

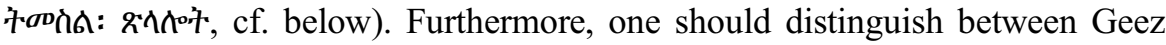

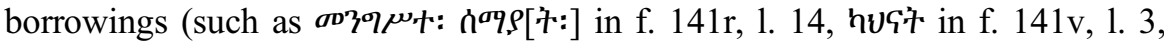
etc. $)^{70}$ and sporadic Geez insertions. The latter are as follows:

70 Geez expressions mentioned as such in Kane 1990 have been considered here as Geez borrowings in Amharic. Obviously, this is an artificial criterion; in reality, there is no sharp borderline between accepted loanwords and sporadic insertions. 
${ }^{\boldsymbol{\sigma o}} \mathrm{C}$ 'वv: hrhC (title);

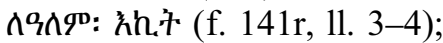

"ทกn't (f. 141r, 1. 8); ;1

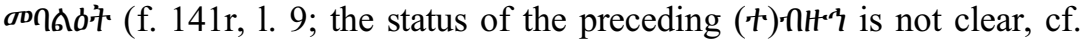

III.3.1);

+5.

III.3.1);

ก中rób (f. 141r, 1. 12);

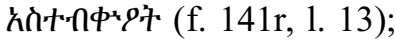

w.4. ․ํ (f. 141r, 1. 13);

कLrttit (f. $141 \mathrm{v}, 1.5)$;

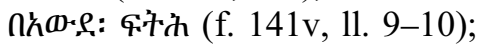

ov30:

gih: P.Q (f. 142r, 1. 2).

There is one phrase whose syntax clearly indicates a Geez insertion: [..3] t:

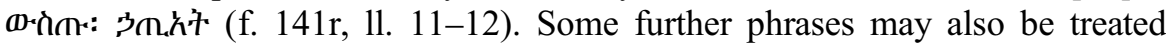
as written in Geez:

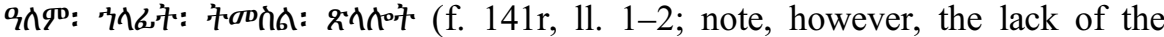
accusative marker $-\ddot{a}$ in $8 \lambda \wedge \circ \%$, which rather suggests an Amharic sentence with Geez loanwords/insertions);

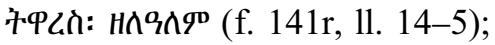

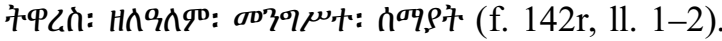

Furthermore, the theological postulates in f. 142r, 11. 5-7 are apparently written in Geez.

\section{III.8. Linguistic traits and the dating of the text}

On the basis of the linguistic evidence one can draw conclusions as to the time of creation of the text. Among other things, the text demonstrates the following archaic features: preservation of some gutturals (cf. III.3.1), right-branching syntax employed side-by-side with head-final structures (cf. III.5.4), non-obligatory status of the postpositional element $\mathbf{- q D}$ in negative main clauses (cf. III.4.5), possibility of employing the simple imperfect in main clauses (cf. III.5.1). According to Girma Awgichew Demeke (2014: 3), these features are typical of pre-eighteenth-century Amharic (cf. also above, I). The estimated time of the composition of MärKL could possibly be the first half or middle of the seventeenth century.

\section{The witnesses of the Märgämä kabr poems}

Until recently, three witnesses of the Märgämä kabr have been known (following Getatchew Haile 2005, 2014, and applying his "labels"): C, in MS EMML no. 5483; E, in MS EMML no. 7007; and J, in MS Jerusalem, JE 541. The complicated relationships among them can be summarized as follows. The end of

71 According to Kane 1990: 14, the lexeme is present in Amharic with the meaning "sacramental bread", while the meaning "bread" (clearly intended here) is restricted to the Shoan variety. 
text $C$ (lines $325-58$ ca.) is related to the last part of text $E$ (lines $311-41 \mathrm{ca}$.). ${ }^{72}$ The initial part of text $\mathrm{J}^{73}$ is related to the initial part of $\mathrm{E}$ (lines $1-137 \mathrm{ca}$.). ${ }^{74}$ At the same time, each witness has extensive text portions not shared with the others. On the present occasion, we would like to introduce a fourth, formerly unnoticed, witness of Märgämä kabr which is transmitted in MS British Library, Orient. $575 .^{75}$ It is very close to text $\mathrm{J}$, so we have assigned to it a provisional siglum " $\mathrm{J}_{1}$ " ${ }^{76}$ MärKL, presented above, is a fifth Märgämä kəbr text. It is different from any of the published or accessible texts, and we can assume, at least for the moment, that MärKL is an independent composition.

An archetype text of the Märgämä kabr could have existed, being the source of some or all known Märgämä kabr poems, but the chance that it may ever be discovered is very small. One may hypothesize how the circulation of the Märgämä kabr poems took place. We can consider several possibilities. The great differences between the texts might have resulted from: 1) wide circulation and transmission through many copies; ${ }^{77}$ 2) the great liberty which the scribes took while copying those texts - using only a certain portion of the exemplar, readily diverging from it, introducing many additional verses, etc. As a result, the differences between the texts are so substantial that in effect each one represents a different recension of the poem, or is a nearly independent work. But the straightforward copying of the poems took place as well (as we observe on the example of $\mathrm{J}$ and $\mathrm{J}_{1}$ ); 3 ) the important role of the oral tradition in the creation and circulation of the poems (cf. below, V).

\section{Märgämä kabr poems and early Amharic literature}

The published poems mentioned in section IV share not so much the text passages but primarily the poetic form of expression and didactic mood. They all convey, of course, one essential religious idea: one should reject the temptations

72 Cf. Getatchew Haile 2014: 446.

73 Denis Nosnitsin has recently visited the library of the Ethiopian Patriarchate in Jerusalem and inspected MS JE 541 (see Ephraim Isaac 1984-86: 74) which appears to be of primary importance for understanding the textual tradition of Märgämä kəbr poems.

74 Getatchew Haile 2005: 255, "Although E and J seem to originate from one source, they are different recensions ... The collation, obviously, is limited to sections where the two documents do in fact have lines in common".

75 Wright 1877: 119-20, no. clxxxvii, the poem occupies ff. 104v-109r. The manuscript was referred to in Cowley 1983b: 23, n. 6, but it has been largely overlooked.

76 The exact relationship between $\mathrm{J}_{\text {and }} \mathrm{J}_{1}$ is still to be clarified. The title Märgämä kabr

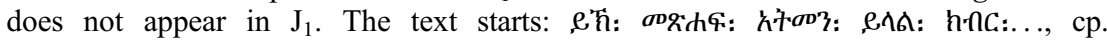
Getatchew Haile 2005: 257, n. 1; there is neither an introductory formula nor a concluding formula. The text is accommodated on the end-leaves but is incomplete (at least one text folio is missing). The text is divided into 12 parts by the word mo raf "chapter" (the same in text J), partly accompanied by a number and in four cases followed by the sentence $\rho$ : sentence 9D3: e+C4.A: Hz 30 : 9dC “What remains except the agony (of death)!" (with some variations).

77 Which would imply that most of those copies have been lost or have not yet turned up. This cannot be completely excluded, because a large number of manuscripts from the essential collections in the relevant regions (Amharic-speaking areas of Gondär, Goğğam, etc.) are still inaccessible. 
of the earthly world in order to avoid eternal damnation; one should take care since one never knows when and how one's life will end. The depictions of the temptations and sins, of death, of the eternal punishment, and of the virtues constitute the main topics of the poems. Elaborating upon them, the poems partly overlap thematically but mostly use different imagery and narrative technique. ${ }^{78}$

If we assume that MärKL is an independent composition, then it seems that its seventeenth-century author was inspired or influenced by other Märgämä $k a b r$ poems. The one who gave it the title Märgämä kabr (the author or copyist?) was aware of the existence of a generic group with such a "label", a few works in Amharic sharing some essential similarities. Based on the conclusions of Getatchew Haile, ${ }^{79}$ we wonder if we should consider the Märgämä $k ə b r$ poems, which are rhymed didactic speech addressed to the community of the faithful, as a specific genre of early Amharic literature ${ }^{80}$ Despite a certain vagueness in their formal characteristics, the Märgämä kəbr poems as a whole are clearly distinct from other kinds ("genres") of early Amharic works. ${ }^{81}$ Moreover, the Märgämä $k a b r$ as a genre can be placed alongside some other Christian literary traditions pivoting on the same main topics, i.e. condemning the temptations and the luxury of the worldly life, preparing the soul for the life after death, etc. ${ }^{82}$

78 Only accidentally do the poems coincide (in motifs rather than in exact wording). For instance, concerning MärKL and the poem in MS EMML 5483, cf. "dead body on a wooden stretcher" (Getatchew Haile 2014, verse 35; cf. verse 55 of MärKL), or "the world deceitful like a night dream" (Getatchew Haile 2014, verse 90; cf. verses 2-5 of MärKL). Parallelism is used intensively in all the poems, but for the rest the narrative technique is not always the same. Only the narrator in MärKL develops his discourse by telling about his "vision" - what "he saw without being asleep". Elsewhere the narrator gives "useful advice" to his listeners (Getatchew Haile 2005, esp. 11. 3-4, 129, 159; Getatchew Haile 2014, esp. 11. 25, 71, 87-88). Formalizing the appearance of the text as a literary work was not considered necessary either. Not every poem employs the (Geez) title Märgämä kabr, and not all have the introductory formula ("In the name of the Father, and the Son...") and concluding formula.

79 Cf. Getatchew Haile 2014: 445, 447 ("During the late seventeenth or early eighteenth century, there came a point when Ethiopian religious teachers developed three approaches for teaching morality and theology in Amharic. These teachings took the forms of "The Five Pillars of Mystery ... catechism and poetry"; "... these texts might not be poems at all, but a third type of speech that stands between prose and poetry, a style that might be called 'Rhyming Prose' or 'Poetic Prose'").

80 i.e. "genre" in the sense of "kind of work" or "literary type", as presented in, e.g., Cuddon 1998: 342, while "prose" and "poetry" are terms referring to the mode of language use (metrically organized compositions vs. those written in "natural", unrestricted language).

81 The Amharic "heroic praise songs" also seem to represent a distinctive genre (being even looser, from the formal point of view, than the Märgämä kabr poems); they were composed and circulated orally, and only in rare cases written down in manuscripts (the so-called "royal songs" are the best known examples, cf. Guidi 1889; Littmann 1914; the "panegyrics" in Getatchew Haile 1979a - warlike praise songs labelled by the composer as religious qane-poems - belong to this genre as well).

82 The Märgämä kabr poems strongly remind us of a sizeable European literary production, in both Latin and vernacular languages, that evolved around the medieval religious concept of contemptus mundi "contempt of the world". Some of the literary devices used for 
The Märgämä kabr poems were composed with the aim of direct religious education of the people, and the poetical mode of expression and the Amharic language were the appropriate means for this. The presence of MärKL specifically in the Missal manuscript MKL-008 is not at all accidental: it would have been meant as a post-liturgical edifying addition to the Missal. ${ }^{83}$ However, it cannot be excluded that the Märgämä kabr poems were created, memorized and circulated mainly orally. In such a form they could easily incorporate according to the needs, the literary skills and the background of the composer - fitting motifs and images originating from works of "elevated" Geez literature on the one hand, and from everyday life and culture as reflected in oral Amharic literature, on the other. Only in some cases were such compositions fixed in written form (see above, IV). Building fluid textual tradition(s), the poems were written down and copied possibly as a kind of aide memoire, providing for users (educated ecclesiastics, preachers?) a ready selection of topics and rhymed passages. This might be one of the ways the nascent Amharic written literature developed. ${ }^{84}$

\section{Abbreviations}

Arb. - Arabic

Arg. - Argobba

Čah. - Čaha

Gnd. - Gndägañ

ヨnm. - ヨnnämor

Gaf. - Gafat

Gez. - Geez

those works were exactly the poetic mode of expression and the vision-form (cf. Gnädinger 1999, Silagi 1999 and other related articles).

83 Of course, the use of the Märgämä kabr would be expected first in the Amharic-speaking area, and not in the core of Tigray. This might be indirect evidence concerning the origin of MS MKL-008, which was possibly produced not in Tigray (but in the Goğğam or Gondär area?) and introduced into the collection of Läq̆ay Kidanä Məḥrät only at a much later time. In assuming this, one immediately thinks of the collection of Mägdäla Mädhane 'Aläm, captured by the British expeditionary troops in 1868, a large part of which was distributed among the churches of northern Ethiopia. The quality of the book and its scribal work might also speak for a place of manufacture outside Tigray. However, better proofs are not available for the moment; direct indications pointing to the Mägdäla Mädhane 'Aläm collection are missing (such as a number written in a European hand on the guard leaf, or an ownership note mentioning that church; see Ancel and Nosnitsin 2014).

84 On the whole, MärKL (and other Märgämä kabr poems?) fits chronologically into the process of the birth of Amharic literature in the seventeenth century as described by Lanfranco Ricci (1969: 852). For the moment, it is unclear whether the Märgämä $k ə b r$ poems can be assigned to what Ricci calls "la controproduzione abissina monofisita in risposta" (to Catholic propaganda), and whether the Märgämä kabr poems had any direct or indirect links to non-Ethiopian and non-Orthodox literary traditions (cf. the surprising conclusions regarding the Old Amharic work Məśtirä şageyat, Goldenberg 2013: 156-7). These issues go beyond the scope of the present article and should be treated in a new history of Amharic literature, which is an obvious desideratum. 
Gr. - Greek

Gyt. - Gyeto

Muh. - Muhər

Tna. - Tigrinya

\section{Bibliography}

'Amməstu 'a madä məsțir. 1952 Am [1959/60 AD]. Addis Ababa: Täsfa mattämiya bet.

Ancel, Stéphane and Denis Nosnitsin. 2014. "On the history of the library of Mäqdäla: new findings", Aethiopica. International Journal of Ethiopian and Eritrean Studies 17, 90-95.

Appleyard, David. 2003. "An 'Old Amharic' commentary on the Nicene Creed", Aethiopica. International Journal of Ethiopian and Eritrean Studies 6, 111-36.

Ayala Takla-Hāymānot, Abbā [Mario da Abiy-Addì]. 1974. La chiesa etiopica e la sua dottrina cristologica. Rome: Saggi ed esperienze.

Bausi, Alessandro. 2010. "Qəddase: Mäșhafä qəddase", in Siegbert Uhlig in cooperation with Alessandro Bausi (eds), Encyclopaedia Aethiopica. Volume 4. Wiesbaden: Harrassowitz Verlag, 279-81.

Biberstein Kazimirski, Albert de. 1860. Dictionnaire arabe-français. I-II. Paris: Maisonneuve.

Bulakh, Maria and Leonid Kogan. 2016. The Arabic-Ethiopic Glossary by al-Malik al-Afdal: An Annotated Edition with a Linguistic Introduction and a Lexical Index. Leiden: Brill.

Chojnacki, Stanisław. 1983. Major Themes in Ethiopian Painting: Indigenous Developments, the Influence of Foreign Models and Their Adaptation from the $13^{\text {th }}$ to the $19^{\text {th }}$ Century. (Aethiopistische Forschungen 10.) Wiesbaden: Harrassowitz Verlag.

Cornill, Carl Heinrich. 1876. "Das Glaubensbekenntniss des Jakob Baradaeus in äthiopischer Uebersetzung", ZDMG 30, 417-66.

Cowley, Roger. 1974. "A text in Old Amharic", BSOAS 37, 597-607.

Cowley, Roger. 1977. "Additional sources for a copula -tt in Old Amharic", Israel Oriental Studies 7, 139-43.

Cowley, Roger. 1983a. The Traditional Interpretation of the Apocalypse of St John in the Ethiopian Orthodox Church. (University of Cambridge Oriental Publications 33.) Cambridge: Cambridge University Press.

Cowley, Roger. 1983b. "Ludolf's fragmentum Piquesii: an Old Amharic tract about Mary who anointed Jesus' feet", Journal of Semitic Studies 28/1, 1-46.

Crass, Joachim, Girma Awgichew Demeke, Ronny Meyer, and Andreas Wetter. 2005. Copula and Focus Constructions in Selected Ethiopian Languages. (Issue 25 of University of Leipzig Papers on Africa.) Leipzig: ULAP.

Cuddon, John A. 1998. The Penguin Dictionary of Literary Terms and Literary Theory, revised by C.E. Preston. London: Penguin Books.

Dästa Täklä Wäld. 1962 Am [1970 AD]. Addis yamarəñ̃̃a mäzgäbä qalat. Addis Abäba: Artistik mattämiya bet.

Dillmann, August. 1865. Lexicon linguae aethiopicae cum indice latino. Lipsiae: T.O. Weigel.

Dobberahn, Friedrich Erich. 1997. "Der äthiopische Begräbnisritus", in Hansjakob Becker and Hermann Ühlein (eds), Liturgie im Angesicht des Todes: Judentum und Ostkirchen I: Texte und Kommentare. Sankt Ottilien: EOS Verlag Erzabtei 
St. Ottilien (Pietas liturgica 9), 137-316 (text); II: Übersetzungen, Anhänge und Register, Sankt Ottilien: EOS Verlag Erzabtei St. Ottilien (Pietas liturgica 10), 1397-1432 (tr.).

Ephraim, Isaac. 1984-86 [1987]. "Shelf list of Ethiopian manuscripts in the monasteries of the Ethiopian Patriarchate of Jerusalem", Rassegna di studi etiopici 30, 53-80.

Encyclopaedia Aethiopica. 2003-14. Vols. 1-5. Ed. Siegbert Uhlig (vols. 1-3), Siegbert Uhlig in co-operation with Alessandro Bausi (vol. 4), Alessandro Bausi in co-operation with Siegbert Uhlig (vol. 5). Wiesbaden: Harrassowitz Verlag.

Fritsch, Emmanuel. 2001. The Liturgical Year of the Ethiopian Church. The Temporal: Seasons and Sundays. Addis Ababa: Master Printing Press (Ethiopian Review of Cultures, Special Issue IX-X).

Fritsch, Emmanuel. 2007. "Mäqdäs”, in Siegbert Uhlig (ed.), Encyclopaedia Aethiopica. Volume 3. Wiesbaden: Harrassowitz Verlag, 765-7.

Fritsch, Emmanuel. 2010. "Tabot: Mänbärä tabot", in Siegbert Uhlig in co-operation with Alessandro Bausi (eds.), Encyclopaedia Aethiopica. Volume 4. Wiesbaden: Harrassowitz Verlag, 804-7.

Geta[t]chew Haile. 1969-70. "Archaic Amharic forms", in Proceedings of the Third International Conference of Ethiopian Studies, Addis Ababa 1966, II. Addis Ababa: Institute of Ethiopian Studies, Haile Selassie I University, 61-80.

Getatchew Haile. 1979a. "Panegyrics in Old Amharic, EMML 1943, f.3v", Israel Oriental Studies 9, 228-36.

Getatchew Haile. 1979b. "Some archaic features of Amharic", in Robert Lee Hess (ed.), Proceedings of the Fifth International Conference of Ethiopian Studies, Session B, April 13-16, 1978. Chicago: Office of Publications Services, University of Illinois, 111-24.

Getatchew Haile. 1980. "Some notes on 'A text in Old Amharic' of Roger Cowley", BSOAS 43, 578-80.

Getatchew Haile. 1983. "Old Amharic features in a manuscript from Wollo (EMML 7007)", in Stanislav Segert and András J.E. Bodrogligeti (eds), Ethiopian Studies: Dedicated to Wolf Leslau on the Occasion of his Seventy-Fifth Birthday, November $14^{\text {th }}$, 1981, by Friends and Colleagues. Wiesbaden: Harrassowitz Verlag, 157-69.

Getatchew Haile. 1986. "Materials on the theology of Qəb'at or unction", in Gideon Goldenberg (ed.), Ethiopian Studies. Proceedings of the Sixth International Conference, Tel-Aviv, 14-17 April 1980, Rotterdam and Boston: A.A. Balkema, 205-50.

Getatchew Haile. 1991. "Qəne poems in Older Amharic", in Alan S. Kaye (ed.), Semitic Studies. In Honor of Wolf Leslau. On the Occasion of His Eighty-Fifth Birthday. November 14th, 1991. Volume 1. Wiesbaden: Harrassowitz Verlag, 521-30.

Getatchew Haile. 2005. "An archaic Amharic poem on condemning wealth and glory", in Geoffrey Khan (ed.), Semitic Studies in Honour of Edward Ullendorff. Leiden and Boston: Brill, 255-75.

Getatchew Haile. 2014. "One more archaic Amharic poem on Christian virtues and vices", in Alessandro Bausi, Alessandro Gori, and Gianfrancesco Lusini (eds), Linguistic, Oriental and Ethiopian Studies in Memory of Paolo Marrassini. Wiesbaden: Harrassowitz Verlag, 445-75.

Girma Awgichew Demeke. 2013. Amharic-Argobba Dictionary. Trenton: The Red Sea Press.

Girma Awgichew Demeke. 2014. Grammatical Changes in Semitic: A Diachronic Grammar of Amharic (Afroasiatic Studies 4.). Princeton and Addis Ababa: WibTaye Publishers. 
Gnädinger, Louise. 1999. "Contemptus mundi, A.C. m. als Begriff und Haltung abendländ. ma. Geistigkeit", in Robert-Henri Bautier, Peter Berghaus and Hermenegild Maria Biedermann (eds), Lexikon des Mittelalters. Stuttgart: Metztler. Bd. III, cols 186-7.

Goldenberg, Gideon. 1974. "L'étude du Gouragué et la comparaison chamitosémitique", in IV Congresso Internazionale di Studi Etiopici (Roma, 10-15 aprile 1972), Tomo II (Sezione linguistica). Rome: Accademia Nazionale dei Lincei, 235-49.

Goldenberg, Gideon. 1976. “A copula + in Old Amharic”, Israel Oriental Studies 6, $131-7$.

Goldenberg, Gideon. 1977. "The Semitic languages of Ethiopia and their classification", BSOAS 40/3, 461-507.

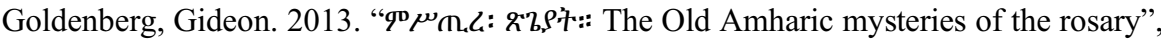
in Gideon Goldenberg, Further Studies in Semitic Linguistics. Münster: Ugarit-Verlag, 155-75.

Goldenberg, Gideon. 2017. "Old Amharic object suffixes and the formation of the d.P\$: '3 $3 \phi$ '”, in Adam Carter McCollum (ed.), Studies in Ethiopian Languages, Literature, and History. Festschrift for Getatchew Haile Presented by His Friends and Colleagues. (Aethiopistische Forschungen 83.) Wiesbaden: Harrassowitz Verlag. 553-61.

Grohmann, Adolf. 1919. Aethiopische Marienhymnen. Leipzig: B.G. Teubner.

Guidi, Ignazio. 1889. "Le canzoni geez-amariña in onore di re abissini", Rendiconti della Reale Accademia dei Lincei, Classe di scienze morali, storiche e filologiche ser 4, 5, 53-66.

Habtä Maryam Wärqənäh, liqü śalțanat. 1963 AM (= 1970/71 AD). Yä-'Ityopya 'ortodoks täwaḩədo betä krəstiyan 'əmnätənna təmhərt. Addis Ababa: Bərhanənna sälam qädamawi Haylä Śəllase mattämiya bet.

Habtemichael Kidane. 2003. “Anaphoras”, in Siegbert Uhlig (ed.), Encyclopaedia Aethiopica. Volume 1. Wiesbaden: Harrassowitz Verlag, 251-3.

Hammerschmidt, Ernst. 1987. Studies in the Ethiopic Anaphoras (Aethiopistische Forschungen 25.) Berlin: Akademie-Verlag.

Heldman, Marilyn E. 2010. "Tabot", in Siegbert Uhlig in co-operation with Alessandro Bausi (eds), Encyclopaedia Aethiopica. Volume 4. Wiesbaden: Harrassowitz Verlag, 802-4.

Kane, Thomas Leiper. 1990. Amharic-English Dictionary. Wiesbaden: Harrassowitz Verlag.

Kane, Thomas Leiper. 2000. Tigrinya-English Dictionary. Springfield: Dunwoody Press.

Krzyżanowska, Magdalena. 2015. "The Gädlä Kiros in Ethiopian religious practices: a study of eighteen manuscripts from Eastern Togray", in Denis Nosnitsin (ed.), Veneration of Saints in Christian Ethiopia (Aethiopica Supplement 3.). Wiesbaden: Harrassowitz Verlag, 95-136 and 249-56 (plates).

Leslau, Wolf. 1956. Étude descriptive et comparative du Gafat (éthiopien méridional). Paris: Librairie C. Klincksieck.

Leslau, Wolf. 1963. Etymological Dictionary of Harari. Berkeley and Los Angeles: University of California Press.

Leslau, Wolf. 1979. Etymological Dictionary of Gurage (Ethiopic). III. Etymological Section. Wiesbaden: Harrassowitz Verlag.

Leslau, Wolf. 1987. Comparative Dictionary of Ge'ez (Classical Ethiopic). Wiesbaden: Harrassowitz Verlag. 
Leslau, Wolf. 1990. Arabic Loanwords in Ethiopian Semitic. Wiesbaden: Harrassowitz Verlag.

Leslau, Wolf. 1995. Reference Grammar of Amharic. Wiesbaden: Harrassowitz Verlag.

Leslau, Wolf. 1997. Ethiopic Documents: Argobba. Grammar and Dictionary. Wiesbaden: Harrassowitz Verlag.

Littmann, Enno. 1914. Die altamharischen Kaiserlieder. Strasbourg: J.H.Ed. Heitz.

Littmann, Enno. 1943. "Altamharisches Glossar", Rivista degli Studi Orientali 20, 473-505.

Ludolf, Hiob. 1698. Lexicon amharico-latinum, cum indice latino copioso. Francofurti ad Moenum: prostat apud Johannem D. Zunnerum.

Mahtämä Səllase Wäldä Mäsqäl. 1962 AM [1969/70 AD]. Zəkrä nägär. Addis Abäba: [no publisher].

Mäșhafä qaddase. 1962 AM [1969/70 AD]. Mäṣhafä qaddase. Bä-gə’azənna bä-'amarəñ̃̃a. Addis Abäba: Täsfa mattämiya bet.

Mersha Alehegne. 2011. The Ethiopian Commentary on the Book of Genesis. Critical Edition and Translation. (Aethiopistische Forschungen 73.) Wiesbaden: Harrassowitz Verlag.

Nosnitsin, Denis. 2013. Churches and Monasteries of Tagray: A Survey of Manuscript Collections. (Aethiopica Supplement 1.) Wiesbaden: Harrassowitz Verlag.

Pankhurst, Richard. 1990. A Social History of Ethiopia. The Northern and Central Highlands from Early Medieval Times to the Rise of Emperor Téwodros II. Addis Ababa: Institute of Ethiopian Studies.

Parkyns, Mansfield. 1853. Life in Abyssinia: Being Notes Collected during Three Years' Residence and Travels in That Country. Volume II. London: John Murray.

Podolsky, Baruch. 1991. Historical Phonetics of Amharic. Tel Aviv: Tel Aviv University.

Praetorius, Franz. 1879. Die Amharische Sprache. Halle: Verlag der Buchhandlung des Waisenhauses.

Rabin, Ira. 2014. "Ink identification to accompany digitization of manuscripts", in Tara Andrews and Carolin Macé (eds), Analysis of Ancient and Medieval Texts and Manuscripts: Digital Approaches. (Lectio. Studies in the Transmission of Texts and Ideas 1.) Leuven: Brepols, 293-307.

Ricci, Lanfranco. 1969. "Letteratura in lingua amarica", in Oscar Botto (ed.), Letterature dell'Etiopia. Como: F. Vallardi.

Richter, Renate. 1997. "Some linguistic peculiarities of Old Amharic texts", in Katsuyoshi Fukui, Eisei Kurimoto, and Masayoshi Shigeta (eds), Ethiopia in Broader Perspective, Papers of the XIIIth International Conference of Ethiopian Studies, Kyoto, 12-17 December 1997. Kyoto: Shokado Book Sellers, Vol. 1, 543-51.

Sernicola, Luisa. 2012. "New archaeological evidence in the area of 'Addigrat (Eastern Təgray) and its surroundings", Rassegna di studi etiopici nuova seria 4, 61-67.

Silagi, Gabriel. 1999. "Contemptus mundi, I. Mittellateinische Literatur", in Robert-Henri Bautier, Peter Berghaus, and Hermengild Maria Biedermann (eds), Lexikon des Mittelalters. Stuttgart: Metztler. Bd. III, col. 188.

Strelcyn, Stefan. 1964. "Ethiopian medical treatises as a source for the study of Early Amharic", in Lalage J. Bown and Michael Crowder (eds), Proceedings of the First International Congress of Africanists, Accra: $11^{\text {th }}-18^{\text {th }}$ December 1962. London: Longmans, 105-12.

Strelcyn, Stefan. 1968. "Le passage $s>t$ en amharique comme objet d'études synchroniques et diachroniques", Rosznik Orientalistyczny xxxi, 2, 127-34. 
Strelcyn, Stefan. 1981. "Les mystères des Psaumes, traité éthiopien sur l'emploi des Psaumes (amharique ancien)", BSOAS 44/1, 54-84.

Uhlig, Siegbert. 1988. Äthiopische Paläographie. (Aethiopistische Forschungen 22.) Stuttgart: F. Steiner.

Walker, Craven Howell. 1933. The Abyssinian at Home. London: The Sheldon Press.

Wright, William. 1877. Catalogue of the Ethiopic Manuscripts in the British Museum acquired since the Year 1847. London: Gilbert and Rivington.

Zelealem Leyew. 2007. "The Amharic dialects revisited", in Rainer Voigt (ed.), "From Beyond the Mediterranean": Akten des 7. internationalen Semitohamitistenkongresses, Berlin 13 bis 15. September 2004. Aachen: Shaker Verlag, 449-80. 